\title{
Judicial Management and Judicial Disinterest: The Achievements and Perils of Chief Justice William Howard Taft
}

\author{
Robert Post
}

William Howard Taft holds the significant distinction of being the only person in the history of the nation to preside over two branches of the federal government. He was President from 1909 to 1913, and he was Chief Justice of the United States from 1921 to $1930 .{ }^{1}$

This achievement ought to have secured Taft a prominent position within the history of the Court. Yet Taft has drifted into almost complete professional eclipse. Although familiar to specialists in legal history, Taft is no more known to the average lawyer or law student than are Chief Justices White, Fuller, or Waite.

Taft's contemporary obscurity is remarkable. When Taft died on March 8, 1930, the nation convulsed in an overpowering and spontaneous wave of mourning. He was widely characterized as "the most beloved of Americans,"2 and hailed by observers like Augustus Hand, then a federal district Judge in New York, as "the greatest figure as Chief Justice since John Marshall."3 Even Felix Frankfurter, certainly no admirer of Taft's jurisprudence, was moved to observe that "Few public men have evoked such spontaneous and warm affection from the public as has Taft. ... He is a dear man-a true human."4

This was a striking tribute to a man who had only eighteen years before been crushingly repudiated. Caught between Theodore Roosevelt's New Nationalism and Woodrow Wilson's New Freedom, Taft was blasted as a reactionary, and managed to obtain only a humiliating eight electoral votes in his 1912 campaign for reelection to the presidency. Taft took defeat graciously, however, and he quickly became, in the famous phrase of journalist George Harvey, "our worst licked and best loved President."s Although Taft had been known as the father of the labor injunction since his days as an Ohio state court judge, he mollified organized labor during World War I by assuming the joint chairmanship (with Frank P. Walsh) of the National War Labor Board. The Board shocked industrial leaders not only by explicitly recognizing the right of American workers 


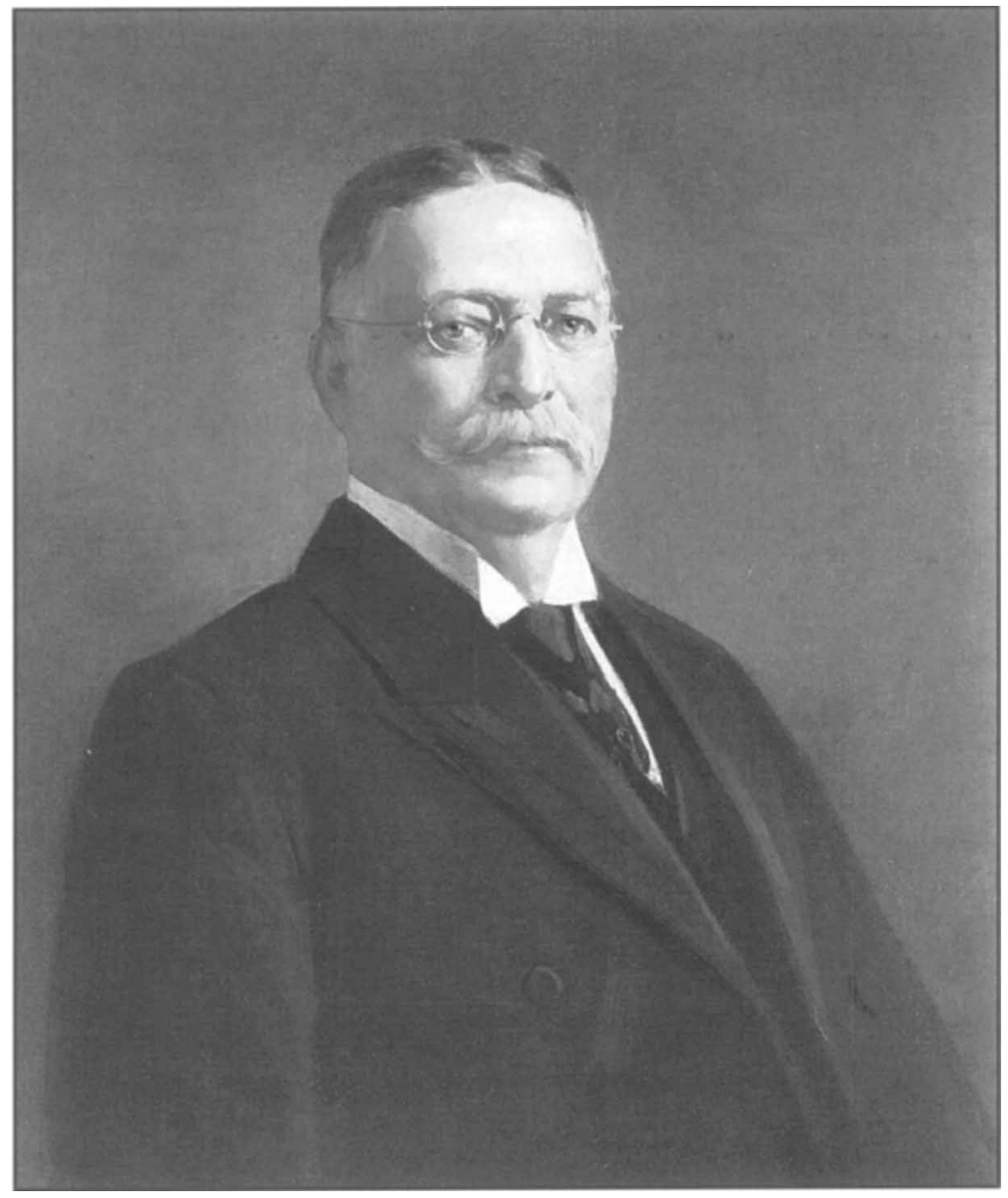

The administrative
responsibilities of the
chief justiceship
became apparent to
William H. Taft
quickly after taking
the oath of office on
July 12 . Two weeks
after being sworn in,
Taft learned that
Deputy Clerk Henry
McKenney had
passed away, leaving
no one authorized to
issue official papers
because the Clerk of
Court, James D.
Maher (pictured),
had died on June 3 .
Told it was
unneccessary to
consult with the
Associate Justices on
summer recess, Taft
unilaterally decided
to appoint Assistant
Clerk William $R$.
Stansbury to fill the
position.

to unionize, but also by pledging official support for the right of employees to receive a "living wage."6 Taft also transcended partisan politics by opposing the leaders of his own party in courageously and publicly championing Woodrow Wilson's campaign to join the League of Nations. As a result, Harding's nomination of Taft for the Chief Justiceship in July 1921 was greeted with "almost unanimous approval."7 It was, as the The New York Times remarked, "a "comeback' unprecedented in American political annals."

We may ask, then, how this man, who, as Walter Lippmann's New York World observed, retired "as Chief Justice with the enduring affection of his countrymen," with a "career" that "has no equal in our history,"9 could have slipped so rapidly into such deep professional oblivion. The short answer, I think, may be found in Time magazine's pithy assessment of
Taft's resignation: "Outstanding decisions: none."10

It is not, of course, that Taft wrote few opinions. Indeed, from October 1921 through July 1929, Taft authored 249 opinions for the Court. The prodigious nature of this accomplishment can be seen by contrasting Taft's output with that of the four other Justices who served continuously during those eight Terms: Holmes wrote 205 opinions for the Court, Brandeis 193, McReynolds 172, and Van Devanter only 94. ${ }^{11}$ It is rather that Taft's opinions were, as Holmes put it, "rather spongy." 12 Although Taft authored a good many opinions that were, within the context of his time, quite important, his writing was seldom crisp or eloquent. ${ }^{13}$ Taft's opinions were often suffused with judicious common sense, which perversely blurred the expression of any sharpedged and therefore memorable jurisprudential vision. ${ }^{14}$ 
Thus, at the time of Taft's death, even his supporters recognized that "His name will not be . . connected with any outstanding decisions - as are the names, for instance, of Chief Justice Marshall and Chief Justice Taney."15 Instead, Taft's unique achievements were said to lie in "his success as an administrator of the complicated functions and activities of the [Supreme Court] ... and his role as a supervisor of the Federal courts throughout the country."16 His "lasting monument" was that he "laid the foundation for a reorganization of the judicial administration in this country." 17 Friend and foe alike acknowledged that Taft "simplified and expedited the processes of the [Supreme] court and greatly improved the administration of justice in the Federal courts." 18 As Charles Evans Hughes accurately observed, Taft's career "fittingly culminated in his work as Chief Justice," because the "efficient administration of justice was, after all, the dominant interest of his public life."19

Hughes' observation suggests an important distinction between Associate Justices and a Chief Justice. The primary task of Associate Justices is to decide cases and deliver opinions, whereas the work of the Chief Justice also includes administrative responsibilities for the judicial branch of the federal government. Taft's current obscurity strongly indicates that enduring professional reputation depends upon the former task, but not the latter. Indeed, when Frankfurter praised Taft as a great "law reformer" and accorded him "a place in history ... next to Oliver Ellsworth, who originally devised the judicial system," 20 he unwittingly revealed what a very small place that is.

It is, however, a place whose corners I shall attempt to illuminate. This paper shall assess Taft's contributions as Chief Justice, rather than his general jurisprudence as expressed through his opinions. It is my hope that by so doing an important but largely overlooked aspect of our judicial history may be excavated. In particular, I shall examine both the birth of the effort to subject federal courts to a regime of efficient judicial management, and the simultaneous origin of important tensions between this regime and traditional American norms of judicial disinterest.
The distinct characteristics of the office of Chief Justice were forcibly impressed upon Taft almost immediately after his appointment. Harding nominated Taft on June 30, 1921, and the Senate confirmed Taft on that same day. At the time Taft was in Montreal, sitting as an arbitrator to determine the value of the Grand Trunk Railway Company, which was being nationalized by the Canadian government. ${ }^{21}$ Taft journeyed to Washington to take the oath of office at the Department of Justice on July 12 . Returning to Canada to his summer home in Murray Bay, Quebec, he was telegraphed on July 30 by Justice Joseph McKenna, the Senior Associate Justice, that Deputy Clerk Henry McKenney had passed away. 22

This posed a serious difficulty for the Court, because its Clerk, James D. Maher, had died on June 3. At the time, federal law provided that the Clerk could only be appointed by the Court. ${ }^{23}$ If the Clerk died, the Deputy Clerk could "perform the duties of the clerk in his name until a clerk is appointed and qualified." 24 With the death of Deputy Clerk McKenney, however, the Clerk's office was, as Assistant Clerk William R. Stansbury telegraphed Taft, "now without an official head and no one authorized to issue official papers." 25 Yet a Court could not be gathered to appoint a new Clerk.

Taft promptly returned to Washington to meet with McKenna. Telegraphic consultation with those Associate Justices who could be contacted proved unhelpful, which, as Taft wrote, "only shows what McKenna assured me that the other members of the Court expect me to attend to the executive business of the Court and not bother them." McKenna impressed the point on his new Chief: "McKenna said I must realize that the Chief Justiceship was an office distinct from that of the Associates in executive control and was intended to be and all of the Associates recognized it, that in judicial decisions all were equal but in management I must act and they would all stand by if ever question was made." 26 Taft boldly and promptly resolved "to do something without statutory authority" 27 and appoint Stansbury "de facto deputy clerk," 28 exacting "a common 
law bond from him to protect everybody." $29 \mathrm{He}$ had learned a valuable lesson about the distinction and prerogatives of the Chief Justiceship.

Chief Justices are typically evaluated as to how well they employ these prerogatives to administer the day-to-day functioning of the Court. They are scrutinized for their handling of small emergencies, like the death of Deputy Clerk McKenney, and for their ability to dispose efficiently of routinized institutional necessities like assigning opinions or moderating the Court's Conferences. Measured by these standards, it is clear that Taft was a highly successful Chief Justice. He was ruthlessly efficient, moving heaven and earth to force the Court to diminish its embarrassingly large back$\log$ of cases. Louis D. Brandeis remarked to Felix Frankfurter that Taft, "like the Steel Corporation, is attaining [all] time production records." 30 In the popular press it was said of Taft that "The spirit of speed and efficiency lurking in the corpulent form of an ex-President of the United States has entered the Court and broken up its old lethargy." 31

Within the Court the dominant image of Taft was not that of a disciplinarian, but rather of a man who could dispose "of executive details ... easily" and "get through them without friction." ${ }_{2}$ "The new Chief Justice makes the work very pleasant," Holmes said. "He is always good natured and carries things along with a smile or a laugh. (It makes a devil of a difference if the C.J.'s temperament diminishes friction.) He is very open to suggestions and appreciates the labors of others. I rather think the other JJ. are as pleased as I am." ${ }^{33}$ Brandeis concurred in this positive assessment:

On the personal side the present C.J. has admirable qualities, a great improvement on the late C.J.; he smoothes out difficulties instead of making them. It's astonishing he should have been such a horribly bad President, for he has considerable executive ability. The fact, probably, is that he cared about law all the time and nothing else. He has an excellent memory, makes quick decisions on questions of administration that arise and if a large output were the chief desideratum, he would be very good. ${ }^{34}$

Taft's genial and winning personality was particularly useful in managing the Court's potentially contentious conferences. Holmes said that "The meetings are perhaps pleasanter than I ever have known them - thanks largely to the C.J." 35 . The Justices also appreciated how "fairly" Taft distributed case assignments. ${ }^{36}$ Indeed, Harlan Fiske Stone later remarked that "there was never a Chief Justice as generous to his brethren in the assignment of cases." 37 Most important, however, Taft exercised a natural leadership within the Court. ${ }^{38}$ As Augustus Hand wrote to him:

You have a certain leadership in the Court that is enormously important and I don't believe has ever existed since the times of Marshall himself. Indeed I think Brandeis, in the left wing, greatly appreciates this and knows how much it means to have a C.J. whom the Court will in certain respects follow and at any rate will "rally around." 39

Supervising the ongoing institutional routines of the Court in this manner has been an essential task of every Chief Justice since Marshall. Some Chief Justices, like Taft, have fulfilled these challenges more successfully than others, but all Chief Justices have understood and accepted these obligations of their office. Taft's unique accomplishment, however, is that he managed to expand the very concept of the Chief Justiceship, so that his successors have also in part been judged by their responses to responsibilities not even perceptible before Taft. "It is certain," Robert Steamer writes in his study of the Chief Justiceship, "that the office was never quite the same after he left it." 40 My concern in this paper will be with the question of how Taft transformed the role of Chief Justice, and my contention will be that he did so by endowing it with a distinctive managerial outlook, one that he had acquired as Chief Executive of the nation.

This claim may sound strange, given Taft's notorious inadequacies as President. Taft readily admitted that as President he felt "just a 
bit like a fish out of water,"41 and that he was "not fond of politics." 42 It was said of Taft that as President he constituted "a very large body completely surrounded by politicians." 43 Indeed, Taft's reputation as a politician was so very bad that he could effectively mock Senator William Borah's denunciation of Taft's own nomination as Harding's effort "to take a politician ... and put him on the Supreme Bench in the interest of party politics": 44

I seem to have heard a suggestion, by way of friendly criticism, when my name was up for the Chief Justiceship, that a politician was being put upon the bench. All I have to say is, that that was news to me (renewed and increasing laughter), and I think it was news to the people. ${ }^{45}$

Yet while Taft may have been, as William Allen White trenchantly put it, "innocent of politics," 46 he was always a capable administrator, determined to improve the efficient management of the executive branch. ${ }^{47}$ And it is this perspective that Taft brought with him into the Chief Justiceship. Most specifically, Taft viewed the federal judiciary as a coherent branch of government to be managed, and he viewed the Chief Justiceship as the source of that management. This perspective was fundamentally new, and its implications were profound.

In the next section, I should like to unfold some of the most salient consequences of this perspective for Taft's reworking of the position of the Chief Justiceship in its relationship to the federal judiciary and to the Congress.

\section{II}

The most obvious expression of Taft's vision of the federal judiciary was the Act of September 14, 1922, ${ }^{48}$ which, as Felix Frankfurter and James Landis have accurately noted, marked "the beginning of a new chapter in the administration of the federal courts." 49 The Act not only authorized the Chief Justice to assign district court judges temporarily to sit wherever in the country the needs of the docket were greatest, ${ }^{50}$ but it also created a
Conference of Senior Circuit Judges to "advise as to . . . any matters in respect of which the administration of justice in the courts of the United States may be improved," and in particular to "make a comprehensive survey of the condition of business in the courts of the United States and prepare plans for assignment and transfer of judges to or from circuits or districts where the state of the docket or condition of business indicates the need therefor." 51 The effect of the Act, as Taft observed, was to introduce "into our judicial system . .. an executive principle to secure effective teamwork," so that "judicial force" could be deployed "economically and at the points where most needed."52 In Taft's view, the primary virtue of the Act was to empower the Chief Justice and the Conference of Senior Circuit Judges "temporarily to mass the force of the judiciary where the arrears are greatest." 53

Taft had been advocating a reform like this for years, ${ }^{54}$ and there was little doubt among contemporaries that the ultimate shape of the statute, as well as its enactment, were "largely the result" of his "active advocacy." 55 Taft lobbied hard for the bill, effectively mobilizing his numerous contacts within Congress, and he rightly received the lion's share of the credit for the results. ${ }^{56}$ Four aspects of the Act of September 14, 1922, require emphasis, because each embodies an outlook on the federal judicial branch that reflects the influence of Taft's experience as President.

First, and most fundamentally, the Act implied "a functional unification of the United States judiciary." 57 Just as the executive branch has always been seen as an integrated whole, directed by the President, the Act for the first time conceptualized federal judges as also integrated into a single, coherent branch of the federal government designed to attain functional objectives. Previously, as Frankfurter has observed, "federal judges throughout the country were entirely autonomous, little independent sovereigns. Every judge had his own little principality. He was the boss within his district, and his district was his only concern." 58 The Act, in contrast, "organized" the "whole judicial force ... as a unit, with authority to send expeditions to spots needing aid."'s9

This idea may seem obvious to us today, 
but in 1922 it provoked great resistance. No less a judge than Henry D. Clayton (after whom the Clayton Act was named) attacked the Act as manifesting "a dictatorial power over the courts unrecognized in our jurisprudence." 60 Clayton objected to "the war idea of mobilizing judges under a supreme commander as soldiers are massed and ordered." He argued that "judges are not soldiers but servants, and the people only are the masters whom they serve." 61

To protests like these, Taft responded with the brutal and implacable language of instrumental rationality. Although he conceded that "in the judicial work a judge does on the bench, he must be independent," Taft insisted that "in the disposition of his time and the cases he is to hear, he should be subject to a judicial council that makes him a cog in the machine and makes him work with all the others to dispose of the business which courts are organized to do."62 The premise that judges are "organized" to accomplish a collective function renders the federal judiciary structurally parallel to an executive agency, which is conceptualized according to a similar logic.

Second, if judges are "cogs in a machine," there must also exist some intelligence that directs the machine. Organizations require guidance, and the functional unification of the judiciary thus implied that the judicial branch be subject to "the executive management" of "a head charged with the responsibility of the use of the judicial force at places and under conditions where judicial force is needed." 63 In this way the Act transformed the federal judiciary from an "entirely headless and decentralized" institution, ${ }^{64}$ into one capable of "executive supervision." 65

Taft defended this transformation as merely a matter of "introducing into the administration of justice the ordinary business principles in successful executive work." 66 He argued that the massive increase in federal litigation required that "we must approach the problems of

In the mind of Chief Justice Taft (pictured), the Chief Justice, using the Conference of Senior Circuit Judges as a kind of cabinet, was responsible for

the management of the judicial branch, just as the President was responsible for the management of the executive branch. His successor, Charles Evans Hughes, sought by contrast to decentralize federal judicial administration.

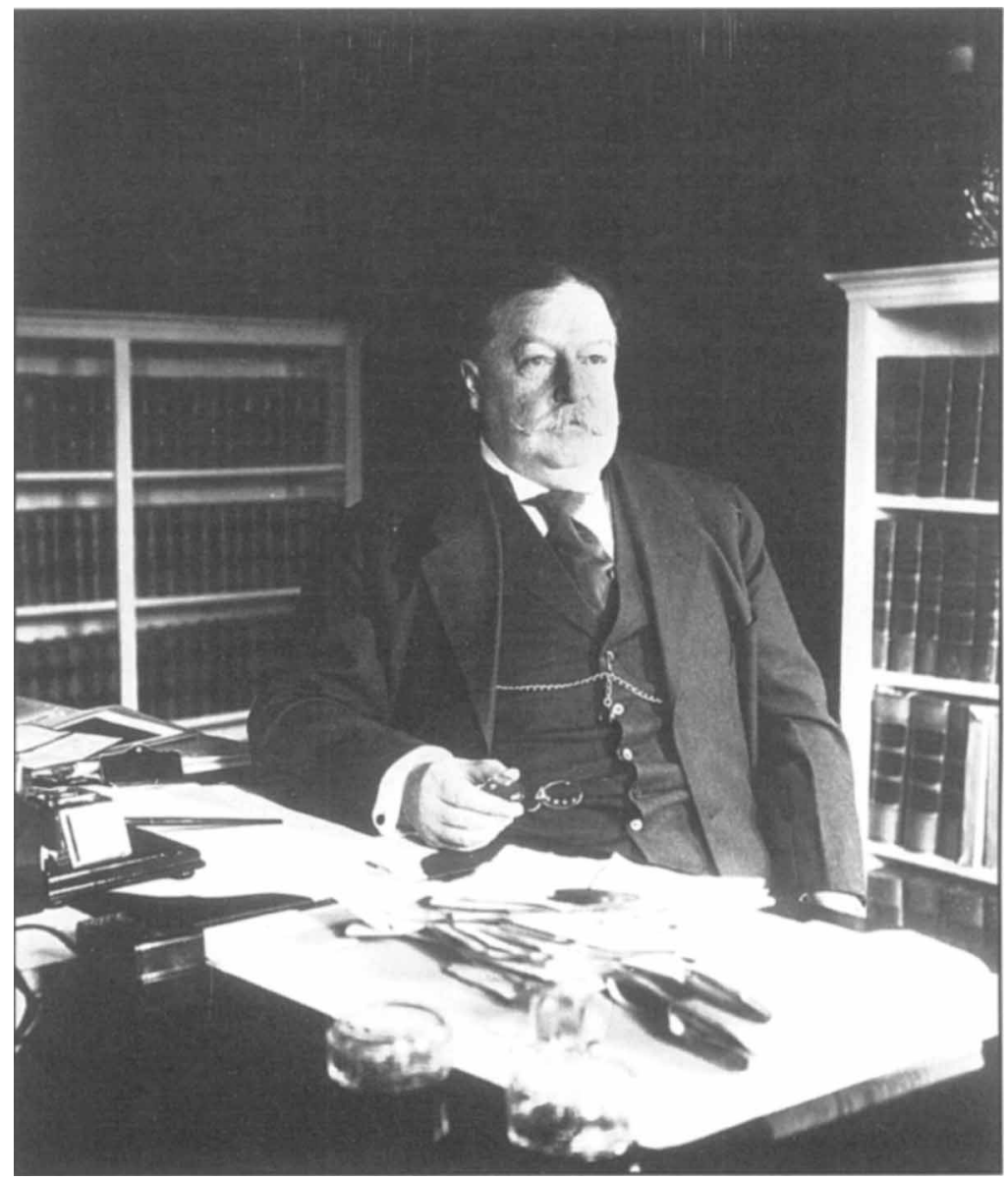


its disposition in the same way that the head of a great industrial establishment approaches the question of the manufacture of the amount that he will need, to meet the demand for the goods which he makes." 67 But in fact the necessity of executive supervision was also central to Taft's conception of the President as ultimately responsible for the "administrative control" of the executive branch. ${ }^{68}$ In Taft's mind the Chief Justice, using the Conference of Senior Circuit Judges as a kind of cabinet, was responsible for the management of the judicial branch, just as the President was responsible for the management of the executive branch. ${ }^{69}$

The managerial obligations that Taft imported into the office of Chief Justice were not exhausted by the operation of the Conference. Taft enthusiastically embraced a sense of generic responsibility for the over-all functioning of the federal judiciary. Exemplary are the letters Taft would write to judges who had failed to decide submitted cases for unconscionably long periods of time:

I write in the interest of the administration of justice, and for the reputation of the Federal Judiciary, that you dispose of the patent case, which you now must have had at hand and submitted to you for more than four years. ... I write this letter with no assumption that I may exercise direct authority over you in the discharge of your duties, but as the head of the Federal Judiciary I feel that I do have the right to appeal to you, in its interest and in the interest of the public whom it is created to serve, to end this indefensible situation. ${ }^{70}$

To accept forthrightly managerial responsibility in this way is not merely to seize the potential of executive supervision, but also to create lines of accountability. For this reason Chief Justice Hughes, when the Court in the 1930 s was subject to withering political assaults, chose to diminish the exposure and vulnerability of such an aggressive managerial posture by seeking as Chief Justice to decentralize federal judicial administration. ${ }^{71}$ But Taft, in the full flush of progressive reform and personal popularity, had no such qualms.
Third, Taft knew that the management of the judicial branch would require the exercise of the deeply human virtues of leadership, inspiration, and a commitment to what Taft repeatedly called "teamwork, uniformity in action and an interest by all the judges in the work of each district." 72 Taft viewed the Conference of Senior Circuit Judges as a means for serving these various management functions. The Conference "is a good thing," said Taft, because it "solidifies the Federal Judiciary" and "brings all the district judges within a mild disciplinary circle, and makes them feel that they are under real observation by the other judges and the country." 73 The Conference was also a method of gathering information about the state of the federal judiciary, of collecting both statistical and narrative data. And the Conference was a tool for "trying to come in touch with the Federal Judges of the country, so that we may feel more allegiance to a team and do more teamwork." 74 The Conference could generate the "esprit" that came from close coordination. ${ }^{75}$

The Conference, however, was only one tool for exercising executive leadership. In fact, Taft seized the opportunity for such leadership in all his dealings with federal judges. He was always "glad to keep in touch with the District Judges," because "they are the wheel horses of our system, and I want them to know that they have the deepest sympathy in their efforts in the dispatch of business." $76 \mathrm{He}$ would write to a Circuit Judge requesting "a long gossipy letter so that I may acquire intimate knowledge of the situation."77 District Judges throughout the nation deeply appreciated this attention and care, and they wrote to Taft expressing their pleasure. ${ }^{78}$ Learned Hand, for example, said to Taft that "It is a great comfort to know the interest that you take. To be frank, we have never felt it before your incumbency."79 As a good executive, Taft wished "to have all the members of the Federal Judiciary realize that we are remanded to the top, and that whatever we can do here in Washington to help, we will do."so

Fourth, the corollary of the functional unification of the federal judiciary was that the judicial branch could now articulate its ongoing and routinized requirements to the legislature, just as did the executive branch. The Con- 
ference was the perfect institutional vehicle for this articulation, and Taft conceived it as enabling "the judiciary to express itself in respect of certain subjects in such a way as to be helpful to Congress." 81 Taft rapidly and effectively molded the Conference into a voice for the institutional needs of the judicial branch. ${ }^{82}$ As he accurately reported to the Conference in 1925: "The recommendations of this Conference have a good deal of influence. I mean that they are accepted as matters for serious consideration." 83

Taft was unwilling, however, to regard the Conference as the exclusive voice of the judiciary. ${ }^{84} \mathrm{He}$ believed quite strongly that the Chief Justice was the primary national spokesman for the cause of the administration of justice, and he therefore sought to maintain an active personal presence in Congress in matters that transcended the pronouncements of the Conference. ${ }^{85}$ In this regard Taft functioned as an independent lobbyist for a legislative agenda, much as he would have as Chief Executive. ${ }^{86}$ It is to this aspect of Taft's conception of the chief justiceship that I would now like to turn.

\section{III}

From the very outset of his chief justiceship, Taft "thought that it was part of my duty" as the head of the federal judiciary, "to suggest needed reforms, and to become rather active in pressing them before" Congress. ${ }^{87}$ Taft was quite aware that this was a new conception of his office. "I don't think the former Chief Justice had so much to do in the matter of legislation as I have," he wrote to his brother Horace, but "I don't object to it, because I think Chief Justices ought to take part in that." 88

Throughout his service on the Court Taft was a frequent witness before congressional committees, lobbying hard for judicial reforms. Taft's relentless determination "to keep pressing" Congress for legislation ${ }^{89}$ began almost immediately after he assumed office. On October 5,1921 , he testified before the Senate Judiciary Committee in support of the Act of September 14, 1922. He realized that he had "violated the precedent in doing this," but he was unfazed, because "I am determined to exercise such influence as I have to help the judicial system of the country. Precedents that keep the judges away from committees who are to help are not precedents that appeal to me."90 By March 30,1922, in the course of testifying before the House Judiciary Committee in favor of bills to enlarge the certiorari jurisdiction of the Supreme Court and to reform the compensation of the Court Reporter, Taft could comfortably remark that "I hate to be in the attitude of a continual beggar from Congress, but I seem to have arrived at the court just when it was necessary." 91

Taft did not hesitate to draft his colleagues on the Court to assist in his lobbying efforts. In 1926, for example, he brought Justices Holmes and Brandeis with him to make the case before a Subcommittee of the House Appropriations Committee for a deficiency appropriation to enable the First Circuit to purchase an urgently needed bar library. "I wanted to bring some big guns to bear," Taft explained. "I am a constant visitor and I did not consider that I had influence enough. This is a real emergency." 92

The presence of Taft's political foes on congressional committees, particularly in the Senate, sometimes rendered his personal testimony counter-productive. In pressing for the legislation reforming the Supreme Court's jurisdiction, for example, Taft learned from Senator Cummins that "some of my old enemies on the [Senate Judiciary] committee rather resent my being prominent in pressing legislation. They want me to "shinny on my own side." 93 So Taft shrewdly selected Justices Willis Van Devanter, James C. McReynolds, and George Sutherland to speak in his place. ${ }^{94}$ Taft testified instead before the House Judiciary Committee. ${ }^{95}$

It is clear, then, that Taft did not regard the chief justiceship as an accommodating civil servant, essentially passive although ready to provide helpful advice when requested by competent legislative authorities. Taft instead understood the position as analogous to an executive official fully authorized to conceive and "push" a legislative agenda. He realized that the responsibility of managing the judicial branch carried within it the ancillary responsibility of promoting legislative reforms that would ensure the effectiveness of such management. The logic of this position remains manifest to this day. Chief Justice William $\mathrm{H}$. 


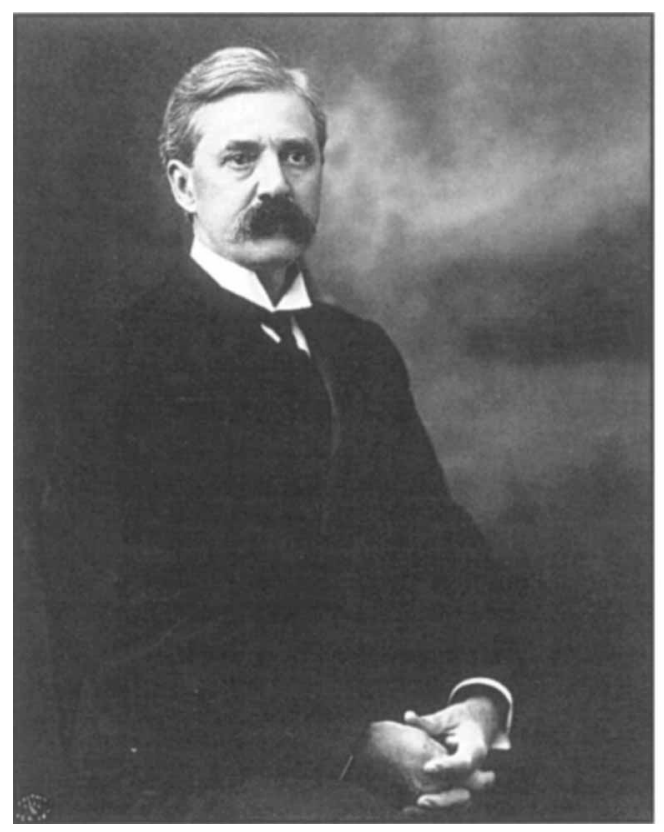

Rehnquist, for example, in a recent annual address on "the state of the judiciary" - an address whose deliberate evocation of the President's annual State of the Union address would have been inconceivable before Taft's transformation of the chief justiceship chose to stress the proposition that the federal courts and Congress "must work together if feasible solutions are to be found to the practical problems that confront today's federal judiciary." 96

A small but telling example of the energetic and comprehensive manner in which Taft pursued this aspect of the chief justiceship may be found in the history of Public Law No. 563, which ended the practice in federal courts of charging defendants with a fee to receive copies of their own indictments. ${ }^{97}$

In November 1925, Taft received a letter from Joseph Coursey, an unknown lawyer from South Dakota, complaining of "the failure of Federal law ... to provide a copy of the charge to the defendant .... It seems to me it should be almost fundamental that a defendant be given as a matter of right a copy of the accusation against him."98 Taft responded by asking Coursey whether the charge for the indictment was imposed "by law, or whether it rests in a local rule of practice." 99 Coursey answered that he did "not know whether the rule is one of law

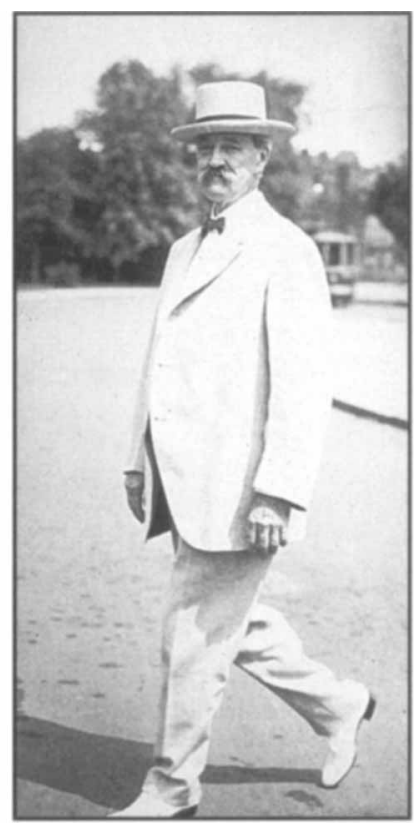

When Taft received a complaint from a provincial lawyer that the government did not provide a copy of the indictment to a defendant, he took the matter up with Solicitor General William Mitchell (right). Despite Mitchell's cautions that doing so would place a financial and bureaucratic burden on the government,

Taft asked Senator Albert Cummins (left), Chair of the Serate Judiciary Committee, to prepare a bill remedying the matter.

or practice but I know positively that in this District we can not obtain such a copy without paying for it except in two cases: namely-if the defendant is charged with homicide or will make a pauper showing."100

Taft then wrote to Solicitor General William Mitchell, asking him to find out "whether it is the practice to furnish defendants with copies of the indictment." He enclosed Coursey's letter, adding "I am rather inclined to think that he has a good case, and that the defendant should be given a copy, at the expense of the Government." 101 Mitchell sent back a detailed, six-page letter, explaining that federal statutes currently required clerks "to charge the accused for copies of the indictments, except in cases involving capital offenses," and that courts had deemed the requirements of the Sixth Amendment satisfied "by the formality of reading the indictment to [the defendant] when he is arraigned." Mitchell went on to caution that "if clerks are directed generally to furnish copies of the indictments without charge to the accused, it would greatly increase the volume of work to be performed in the clerk's office, particularly on account of the large number of cases under the National Prohibition Act, and that the clerks' offices are now shorthanded as the result of lack of adequate appropriation."102 
Not deterred by Mitchell's warning, Taft wrote to Senator Albert Cummins, Chair of the Senate Judiciary Committee, explaining the situation and commenting that "I should think ... that the Government ought to furnish, at its own expense, indictments to defendants."103 Taft viewed the question as one of justice, rather than constitutional compulsion, and he dismissed the potential bureaucratic burden with the observation that clerks could easily type indictments in triplicate. Cummins agreed with Taft's assessment, and he asked Taft to "prepare a Bill relating to furnishing copies of indictments to defendants and send it to me. I will be glad to introduce it." 104

Taft requested that Mitchell draft a bill, which the Solicitor General did, noting that "those in charge of the appropriations for the Department of Justice have estimated that" the bill would "substantially increase the expenses of operating the offices of the clerks of the courts. ... I have explained, however, that this Bill is not being furnished you as a Department measure, but merely as the result of a personal request for a document to supply Senator Cummins' wants." 105 Taft forwarded Mitchell's draft to Cummins, who agreed to "introduce the bill and have it referred to the Committee."106 The result was Public Law No. 563, which became law in January 1927.

That Taft would take the time to evaluate the complaint of an unknown, unsophisticated, and provincial lawyer, that he would summon the energy and will to remedy that complaint in the face of bureaucratic opposition, that he could command the personal respect and assistance of leaders in the executive and legislative branches in this task, all reveal much about Taft's construction of the role of Chief Justice. In Taft's eyes, the chief justiceship was much closer in spirit and responsibility to the English position of Lord Chancellor, an executive official whose portfolio included the administration of justice, than to any previous American model of a federal judge.

The English model of an executive judicial official did not, however, fit easily into American circumstances. Reform in the American context often required political mobilization, which potentially conflicted with traditional American norms of judicial nonpartisanship.
Taft was keenly aware of this tension. When Taft became Chief Justice he gave up an editorial column in which he had commented regularly on current events, stating:

The degree in which a judge should separate himself from general activities as a citizen and a member of the community is not usually fixed by statutory law but by a due sense of propriety, considering the nature of his office, and by well-established custom. Certainly, in this country at least, a judge should keep out of politics and out of any diversion or avocation which may involve him in politics. It is one of those characteristic queer inconsistencies in the British judicial system, which was the forerunner of our own, that the highest judicial officer in Great Britain, the Lord Chancellor, is often very much in politics and has always been. ${ }^{107}$

The passage is noteworthy because it casts a wistful glance at the office of the English Lord Chancellor at the very moment that it acknowledges distinctively American obligations of judicial disinterest.

Despite his good intentions, Taft very quickly found that he could not contain his "bursting expression." $108 \mathrm{He}$ believed that he could reconcile his commitment to law reform with American judicial norms by speaking out only to bar associations in order to mobilize them to lobby in support of measures for the reform of the administration of justice. "One of the most important extra curriculum things that I have to do as Chief Justice," he said, is "to organize the Bench and the Bar into a united group in this country dedicated to the cause of the improvement of judicial procedure." 109 Elihu Root in fact commented to Taft that he was "the first Chief Justice to fully appreciate the dynamics of the Bar as an organization. If a national bar spirit can be created it will have an immense effect upon the administration of justice."110

Taft began his program of mobilizing the bar almost immediately upon taking office. On August 30, 1921, he spoke to the Judicial Section of the American Bar Association, seeking 
support for what would later become the Act of September 14, 1922.111 Four months later, he spoke to the Chicago Bar Association, seeking support for the Act, as well as for the simplification of federal procedure and the expansion of certiorari jurisdiction in the Supreme Court. ${ }^{12}$ These speeches were criticized on the floor of the United States Senate as "different from those made by any other Chief Justice."113 Senator William J. Harris of Georgia opined that "the judiciary is going to be injured, and the people will not have the same high respect for it if the Chief Justice and associate justices of the Supreme Court of the United States make speeches in public not in their line of duty as has been done recently." 114

Taft, however, was defiant. Three days later he shot back in an address to the New York County Bar Association:
I venture to think that there are some things that a judge may speak of and may discuss in public and not use a judicial opinion for the purpose. The subject is that of law reform. From the earliest traditions of the English bench from which we get our customs, the judges of the highest courts of Great Britain have taken an interest in and a part in the formulation of legislation for bettering the administration of justice. They have written and spoken on such subjects with entire freedom and without incurring criticism. You doubtless remember that in Campbell's Lives of the Lord Chancellors and the Chief Justices, a part of the story of each life is work done in law reform. Measures of this sort that are put through in England are

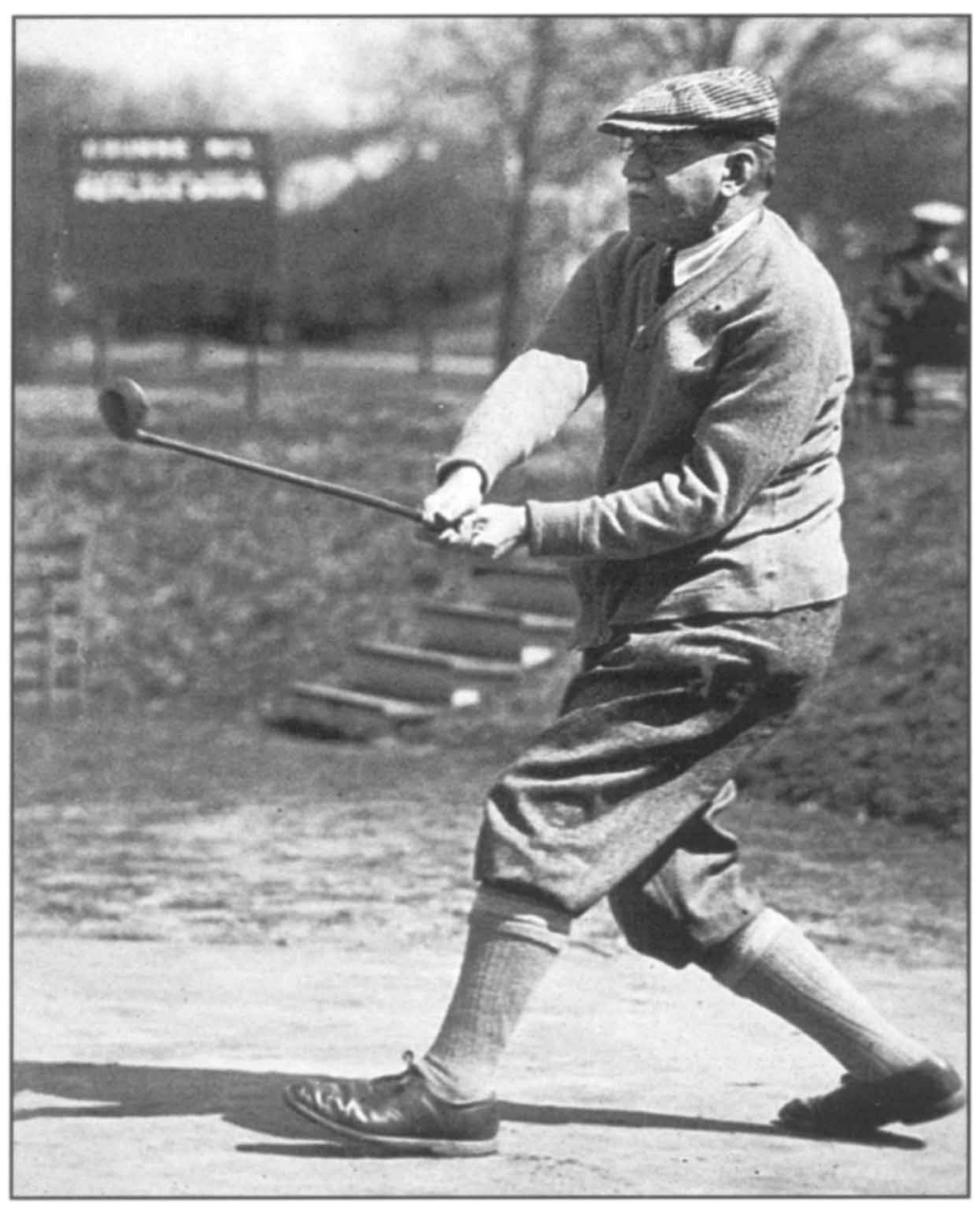

Taft prevailed on his brother, Henry $W$. Taft (left), to help rouse opposition to S. 3151, a bill that stripped federal district courts of both federal question jurisdiction and diversity jurisdiction. Despite being an influential member of the New York bar and a named partner at Cadwalader, Wickersham \& Taft, Henry was ineffective at generating publicity in the influential New York newspapers. 
usually prepared by the law officers of the government and sometimes by the Lord Chancellor himself. The judges of the Supreme Court have taken an active part in the discussion of the measures as they go through their legislative course. And why should it not be so? With their attention constantly directed toward the workings of the machinery of the administration of justice, they are at a more advantageous point of observation and if they use their opportunities, are better able to make recommendations with respect to law reform than any other class in the community. ${ }^{115}$

Taft never did retreat from his program of mobilizing political support for the cause of judicial reform. He understood well enough that American judges were appropriately reluctant to engage "in extra-judicial activities" because they might be cast into positions "actually or seemingly inconsistent with absolute impartiality in the discharge of . . judicial duties." 116 But, explicitly invoking the precedent of the English Chancellors, Taft apparently believed that advocacy of judicial reform would not compromise his judicial impartiality because, as he said, he could "discuss" this subject "in public and not use a judicial opinion for the purpose." As a good child of the Progressive era, Taft seemingly regarded judicial reform as purely technical and apolitical. ${ }^{117}$

But of course in the American context any such belief is merely naive, and so in at least two distinct ways Taft's public advocacy sometimes threw him perilously close to violating judicial norms of disinterested neutrality. First, in America there was simply no clear line distinguishing judicial reform from partisan politics. This can perhaps best be illustrated by Taft's opposition to S. 3151, a bill sponsored by Progressive Republican Senator George Norris of Nebraska and strongly supported by Democratic Senator Thomas Walsh of Montana, who was later selected by Franklin D. Roosevelt as Attorney General. The bill stripped federal district courts of both federal question jurisdiction and diversity jurisdiction. ${ }^{118}$ By a stroke of great irony, Norris, who thoroughly disliked federal courts-he had ac- tually once proposed abolishing all federal courts except the Supreme Court ${ }^{119}$-was the Chair of the Senate Judiciary Committee. Remarkably, S. 3151 was reported favorably by the Senate Judiciary Committee without even a hearing. ${ }^{120}$

Taft was appalled by what he regarded as "the remarkable effort made in the Senate by Norris and Walsh to emasculate the jurisdiction of the Federal trial courts ... and to sneak it through without the country's being advised about it."121 He saw the bill as "a great attack on the administration of justice in this country," 122 the "most radical bill affecting the usefulness and efficacy of the Federal Judiciary that I remember ever to have heard suggested."123 Taft threw himself into the task of "trying to save the life of the Federal Judiciary." 124

It quickly became apparent, however, that Taft's opposition to S. 3151 could not be confined to the nonpartisan expression of expertise. Thus when Taft wrote "to sound an alarm on the subject" to his friend Casper Yost, editor of the influential St. Louis Globe-Democrat, he cautioned that "I am so situated that I can not take a political part, but ... I invoke your influence in maintaining the protective power which citizens may secure from the Federal Judiciary in defense of their rights." 125 Yost responded by publishing a lively editorial. ${ }^{126}$

That Taft thoroughly understood and was willing to exploit the explosive politics of S. 3151 is evident from a letter he sent to his brother, Henry W. Taft, an influential member of the New York Bar, ${ }^{127}$ urging him to begin a public campaign against the bill:

Now my own judgment about this bill is that if Norris tries to get it through, and is supported by the Democrats, it will prove to be dynamite in the next campaign. It will rouse every negro in the United States, and they cast a great many votes now in the large cities since they have moved north, and when it becomes known to them that they can not resort to the local Federal courts, they will certainly be convinced, as they ought to be, that they are suffering a practical deprivation of their Federal 


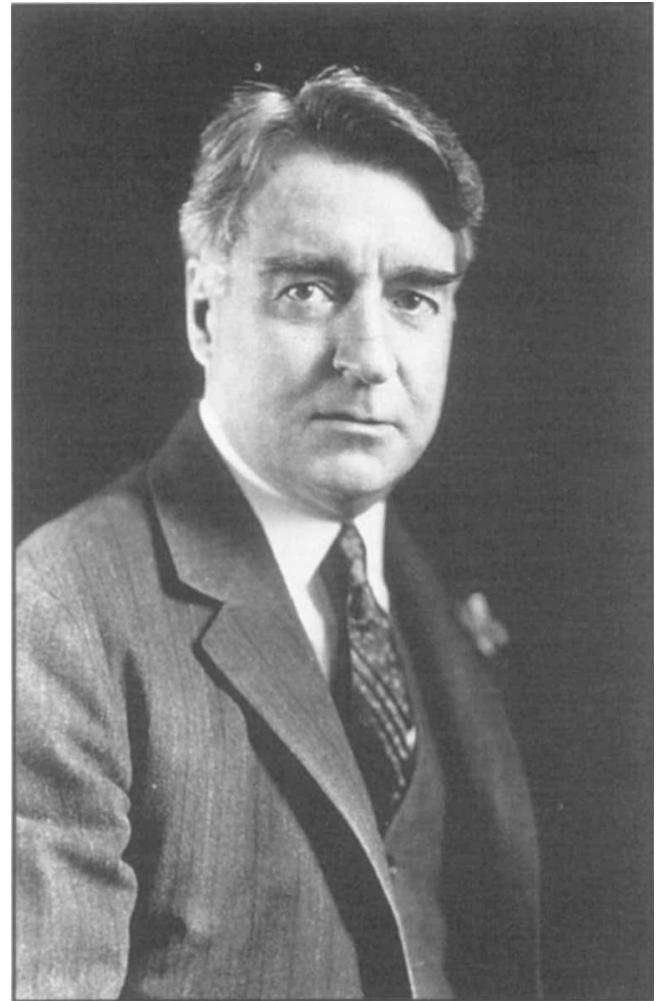

Although Taft tried to keep out of the political debate over bill S. 3151, Senator Royal Copeland of New York (above) told his colleagues on the Senate floor that the Chief Justice opposed it. The bill was amended to restore federal question jurisdiction.

rights and protection. I think you ought to go to the New York Times and to the Tribune and explain the effect of the bill and have editorials printed on the subject. Reference to the negroes will find an echo, and I am quite sure that the Times will feel like warning the Democratic party against any such radical measure. I think you ought to bring it to Hilles' attention and that the opposition to it ought to be made a plank in the National Republican Platform. ${ }^{128}$

When Henry proved inept in generating publicity, paralyzed by Charles Evans Hughes' fear that anything "coming from New York" would be dismissed as reflecting "Wall Street interests," 129 Taft lost patience. 130 "What I was anxious to do," he explained, "was to head the movement by an announcement in the New York Times, for there are a great many people who look to the Times as a kind of Bible."131 Henry accepted the "rebuke" and promptly contacted Rollo Ogden, editor of The New York Times. ${ }^{132}$ On April 22 the Sunday Times published an editorial strongly opposing the bill. 133

The fierce controversy that surrounded S. 3151 simultaneously concerned politics and the administration of justice; the two were inseparably combined. Taft knew that he could not risk overt involvement, yet his name and views figured prominently in the debate. On the floor of the Senate, for example, Senator Royal Copeland of New York, seeking to have the bill remanded to the Committee for hearings, observed that "I am advised by the attorneys who have spoken to me that the Chief Justice of the Supreme Court feels that the bill is not a good bill in some respects." 134 In its editorial, The New York Times specifically referred to this comment, remarking that "It is no secret, since the fact was stated in the Senate by Mr. Copeland of New York, that the Chief Justice of the Supreme Court regards some of the features of this bill as most undesirable and harmful."135 Two weeks later, Senator Duncan Fletcher of Florida had reprinted in the Congressional Record an editorial in the American Bar Association Journal strongly opposing $\mathrm{S}$. 3151 , which relied heavily on arguments attributed to Taft, ${ }^{136}$ as well as an editorial from the Florida Times Union that opposed the bill in part on the grounds that "the Chief Justice of the United States Supreme Court ... is reported to have said that this bill has features that can be regarded only as most undesirable and harmful." 137

As a result of the accumulating pressure, Norris was forced to amend his bill to restore federal question jurisdiction. ${ }^{138}$ Taft wrote Henry, "I think Norris has heard a good deal about his proposed changes, and ... he does not find them so easy to push through as he thought he would, in view of the agitation you have all stirred up on the subject."139 Norris' revised bill eventually stalled in the Senate. Yet Taft's intense struggle to defeat it illustrated the uneasy line between disinterested law reform and unabashedly political mobilization.

The second reason why Taft's appeal to an English model of an executive judicial official was dangerous in the American context con- 
cerned the institution of judicial review. Each time Taft became involved in legislative reform, he risked prejudging the constitutionality of proposed legislation. This potential lurked even in the most technical and benign measures. The point can be illustrated by Taft's involvement in the passage of a bill that transferred jurisdiction of patent appeals from the Court of Appeals of the District of Columbia to the Court of Customs Appeals. Taft strongly supported the bill, to the extent that Acting Commissioner of Patents William A. Kinnan could in congressional hearings testify that "There has been no objection anywhere. It has been indicated that the Chief Justice of the United States has looked into it and approved it. It seems to me to be an efficiency measure."140

Taft wrote to Senator Thomas Walsh on May 8,1928 , urging approval of the bill on the grounds that the District Court of Appeals was "very much burdened with business," while the Court of Customs Appeals did "not have enough to do." 141 Despite his ongoing struggle with Walsh over S. 3151, Taft was sweetly and nonpartisanly solicitous: "I am sorry to impose on you, my dear Senator, another burden, but as I understand you are on the committee for the consideration of this bill, I venture thus to write to you. It will certainly help the administration of justice in the District." 142 Most striking from a modern point of view, however, is that Taft included in his letter a long defense of the bill's constitutionality, which began:

I understand that there are two persons who think that the bill is unconstitutional. I can not for the life of me understand how any such doubt could arise. The Court of Customs Appeals is a purely statutory court, and Congress is not limited in any way in the functions which it gives to it. ${ }^{143}$

Walsh replied to Taft that he would "make an effort to have the matter put in" shape for approval, ${ }^{144}$ and the bill, seemingly uncontroversial, was enacted into law March 2, 1929.145

It is remarkable that Taft would submit an advisory opinion about the constitutionality

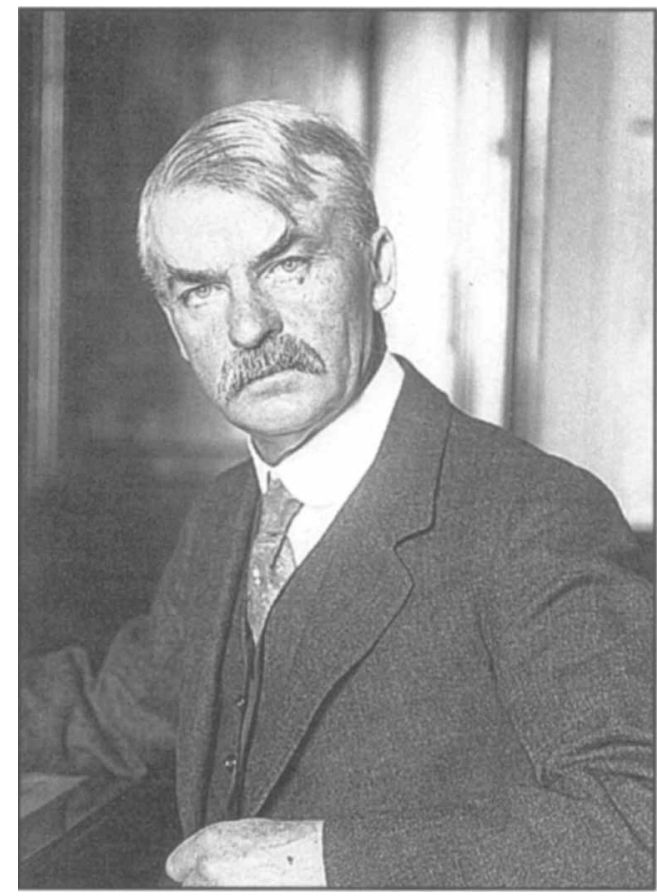

In order to make clear his suppport for a bill that transferred jurisdiction of patent appeals from the Court of Appeals of the District of Columbia to the Court of Customs Appeals, Taft wrote to Senator Thomas Walsh (above), the most influential Democrat on the Senate Judiciary Committee, outlining why he thought the bill was constitutional. Apparently, the Chief Justice felt free to give constitutional advice to a political opponent.

of a statute to a Senator who was in many ways his archopponent. It indicates how unembarrassed Taft must have felt about the practice. Apparently he regarded the constitutional issues posed by the statute as uncontroversial and settled. But constitutional judgment in the United States is seldom a secure thing. Taft premised his argument on the fact that the Court of Customs Appeals was an Article I court, yet within only thirty years Congress would itself declare the (now renamed) Court of Customs and Patent Appeals an Article III court, ${ }^{146}$ a conclusion sustained by the Supreme Court of the United States. ${ }^{147}$

In this country, as distinct from England, the institution of judicial review renders advisory opinions dangerously uncertain, and this poses a powerful dilemma for a Chief Justice who would accept responsibility for pushing a 
legislative agenda for judicial reform. For legislative change cannot be proposed without being endorsed, and how could Taft endorse legislation without rendering an advisory opinion? 148

The dialectic of this dilemma is vividly exposed in the story of Taft's attempt to relieve federal courts of the flood of small criminal cases that Prohibition had swept into their jurisdiction. Not only did these cases clog the docket, but federal judges found them intensely demoralizing. ${ }^{149}$ Almost from the day he took office Taft believed that legislation was needed to allow United States Commissioners to try such cases. ${ }^{150}$ In 1923, at the second meeting of the Conference of Senior Circuit Judges, Taft pushed through a resolution to the effect that "in prohibition and other misdemeanor cases" U.S. Commissioners be authorized "in all cases in which the defendants do not file written demands for jury trial, to take and file written pleas of guilty and to hear the evidence on pleas of not guilty and to file in court their reports of the cases and their recommendations of what judgment should be entered."151 Taft regarded this resolution as one of the "most important" of the Conference. ${ }^{152}$

The recommendation went nowhere, however, and so in December 1925 Taft on his own initiative sought to revive the plan. He wrote to Representative George S. Graham, Chair of the House Judiciary Committee, and to Senator Albert Cummins, Chair of the Senate Judiciary Committee, that he was "very much troubled about the conditions that prevail in the District Courts of the United States. They are being demoralized by this police court business." Taft proposed an elaborate legislative scheme to remedy the situation.

How would this suggestion strike you? Provide that in every District there should be appointed a Judicial Commissioner to serve during good behavior, that he should have authority to hold court, try jury trials and have jurisdiction to try misdemeanors and felonies, punishment for which shall not exceed two years' imprisonment; that he should be given the power to compel the defendants to elect whether they desire

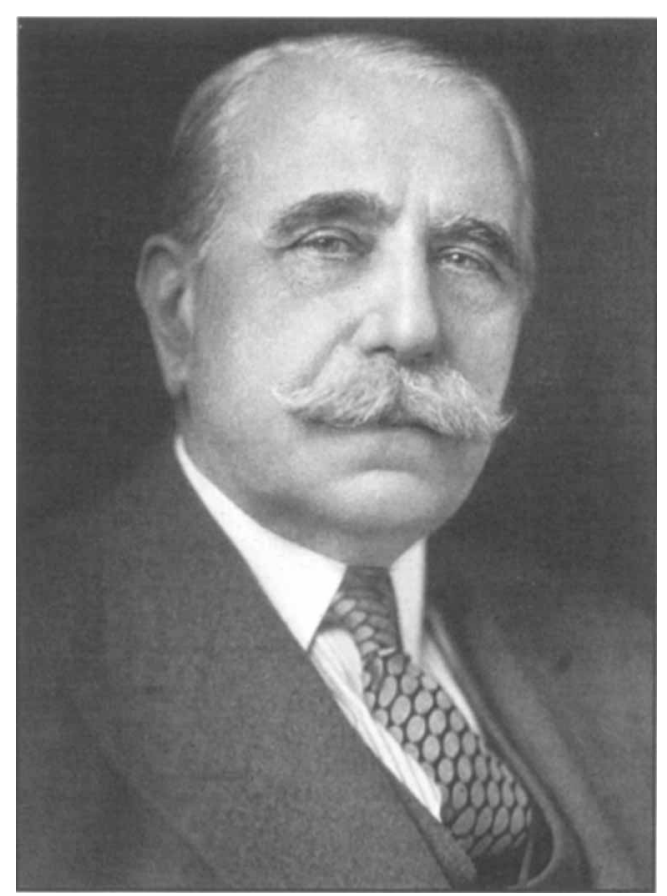

Representative George Graham (above), Chair of the House Judiciary Committee, told Representative Duncan Denison of lllinois that the Chief Justice had merely alerted members of Congress to a problem in need of solution, without proposing any particular legislative response. This was, in fact, untrue: six months earlier Taft had written to Graham to propose legislation to allow U.S. Commissioners to hear cases arising from Prohibition so as to keep the petty criminal cases from clogging federal dockets.

jury trials within ten days after the filing of the information or the indictment; that he should be required to act also as a regular United States Commissioner, and might be called upon by the District Judge to act as a Master in Chancery or a Referee.... I don't think he thought to be appointed by the President, but that as Judicial Commissioner his might be regarded as an inferior office, and under the Constitution he could be appointed by the District Court .... Can not you think this over and frame a bill? Something ought to be done. I just throw out this suggestion, with the hope that it may germinate into something. ${ }^{153}$ 
Six months later, in the course of debate on a bill to authorize the appointment of additional district judges, Representative Graham observed on the floor of the House that he was "in conference with representatives of the Senate Judiciary Committee and some of the judges of the Supreme Court trying to work out some scheme by which the courts of the United States might be relieved of some of the very heavy burdens which they are now obliged to carry." Graham pledged to "strive to create some plan by which a minor judiciary may be created."154 Representative Duncan Denison of Illinois rose to inquire into "the wisdom of taking into these conferences, in trying to work out legislation that will relieve the courts of a part of their work, the members of the Supreme Court. Does the gentleman think that is a wise policy?"155 Thrown on the defensive, Graham quickly backpedaled:

Mr. GRAHAM, Well, without passing any opinion upon the wisdom of the policy, it came about without our solicitation and we attended simply as conferees.

Mr. DENISON. In the constitutional convention . . that theory was abandoned as being unwise, the theory of having the Supreme Court advise the Congress as to legislation, and I think if we should return to that policy it would be a dangerous one.

Mr. GRAHAM. I may say that this conference arose and was called through the intervention of the Supreme Court judges, upon one of whom, the Chief Justice, there depended the duty of reviewing the work in the district courts all over the United States in the congested districts and trying to provide a remedy. He simply called the chairman and the ranking member of each Judiciary Committee in to ask them to take up the subject and see if there could not be some plan devised. That is all.

Mr. DENISON. What I have in mind is this. Suppose the Congress should enact legislation that is intended to create some sort of subordinate courts to relieve the other courts of some of their duties, and afterwards the constitutionality of the legislation should be raised in the courts, if the Supreme Court had been consulted and advised in the preparation of the law, it seems to me it would be embarrassing, and I do not believe the committee of the House ought to do that.

Mr. GRAHAM. I think, perhaps, ethically the gentleman is correct, and I am not going to dispute that proposition, but I do say it was perfectly competent for those who had charge of the court business throughout the country to call our attention to it and ask us to take it up independently; and that is all that was done.

\section{Mr. DENISON. I see no objection to that.}

Mr. GRAHAM. That is all that was done. They would not be taken into consideration in framing the legislation for the legislative duty would rest upon the House and the Senate. ${ }^{156}$

The dialogue crisply captures the dilemma of any American Chief Justice aspiring to advocate legislative reform. Representative Graham deftly defused Denison's challenge by asserting that Taft had merely called the attention of members of Congress to a problem in need of solution, without proposing any particular legislative response. But we know from Taft's correspondence of six months earlier that this was not true. Had the real facts been known, Taft's "embarrassment" would indeed have been acute.

Taft apparently took the point. When Frances Caffey subsequently wrote him to inquire about the status of the 1923 recommendation of the Conference of Senior Circuit Judges so as to be able more effectively to lobby for bills expanding the jurisdiction of U.S. Commissioners then pending before Congress, ${ }^{157}$ Taft responded with uncharacteristic caution: "I have to be careful in taking part myself in the preparation of such a bill, because any bill is likely to come before our Court for interpretation and inquiry into its validity." 158 Taft's zeal to refashion judicial administration had been checked by the institutional realities of American judicial review.

Sometimes, however, that zeal pushed Taft plainly beyond what would today be regarded 
as elementary norms of judicial propriety. The strong temptations generated by his urgent sense of responsibility for the federal judicial branch are well revealed by his struggle against S. 624 , a bill sponsored by Senator Thaddeus Caraway of Arkansas that would make it reversible error for a federal judge to comment on the credibility of witnesses or the weight of the evidence. ${ }^{159}$ Most states prohibited judges from such comments, and Taft had long regarded these prohibitions as empowering "acute and eloquent counsel for the defense" to promote "an atmosphere of fog and error and confusion," and so drastically to impede the orderly administration of justice. ${ }^{160}$ For decades he had taken every opportunity passionately to oppose them. ${ }^{161}$ So when S. 624 was approved by the Senate Judiciary Committee and then by the Senate itself, Taft was galvanized into action.

"I am trying to prevent the passage of a bill aimed at the usefulness of the Federal courts," he wrote to his wife:

which seeks to deny to Federal Judges the power to comment on the evidence as the English Judges do. This has always been done in the Federal Courts and has contributed much to their effectiveness. Now these demagogues and damage lawyers are attempting to put the Federal Courts on the basis of the State courts in this regard. The bill has passed the Senate and the Senators yielded supinely, except Reed of Pennsylvania. It has been reported out of the House Judiciary Committee, but I am hoping to hold it over until the next session, in which case I feel fairly confident that I can induce the President to veto it, and I believe his veto would prevent its passage. There is a serious question as to whether it is constitutional, but I would prefer much to have it beaten through a veto than to throw upon the Court the question of its constitutionality. ${ }^{162}$

Taft attempted to secure a commitment from Judiciary Committee Chair George S. Graham to hold hearings on the bill in the House, and he sought "to have the various Bar Associations ... apply to the committee to be heard upon this bill in opposition to it, both on the ground of its doubtful constitutionality and also because of its interference with the efficiency of the Federal courts." 163

Not content with this blatantly political maneuvering and mobilization, Taft on December 2, 1924, composed a remarkable Memorandum in opposition to the bill. The cover sheet to the Memorandum, which Taft apparently drafted for his own records, states:

I am exceedingly anxious to beat the bill . . because it will really greatly interfere with the Federal judicial system. I was able to hold the bill off last session through Chairman Graham and Snell of the Rules Committee in the House. I have been to see the Attorney General once or twice about it and I saw the President this morning and asked him to read this memorandum. I am quite sure that he will be inclined to veto the bill, but it ought not to come to him, and I think the Attorney General suggests his sending for Graham and Nick Longworth to see whether it can not be shelved. I submitted the memorandum to Van De Vanter [sic] and he fully approved the statement, but he thought that I put a little too much admiration for the English in it. However, as this is not to be published and is only a confidential memorandum for the President and the Attorney General, and as I have only given out one copy in addition to that given to Van Devanter, there is no occasion for changing my view which is stated herein, or ameliorating it with reference to prejudices against England. ${ }^{164}$

The Memorandum itself is a twelve-page document arguing that the Caraway bill would greatly "weaken the usefulness and efficiency of Federal Courts in the dispatch of business involving jury trials." 165 On page six the Memorandum addresses the "question ... whether Congress may by law effect this demoralizing 
assault on the trials in our Federal Courts. Fortunately the right of the Judge to exercise this power of summing up to a jury upon the facts is conferred upon him by the Constitution of the United States, and can not be taken away by legislation." 166 The remainder of the Memorandum constitutes a detailed argument for this proposition, concluding:

In view of these authorities, it can not be that Congress may take away the power of a Judge of a United States Court in carrying on a jury trial, to comment on the evidence and even express his opinion on the facts, if he leaves the question of facts clearly to the jury ultimately. It was an essential element of a jury trial in the English courts when the Declaration of Independence was signed and our Constitution was framed and adopted and when the 7th Amendment became part of it. That being true, Congress may not impair the institution by attempting to restrain Federal Judges from the discretion to exercise the power vested in them by the fundamental law. ${ }^{167}$

The Memorandum is a stunning document. It is a fully developed advisory opinion, crafted by Taft for the explicit purpose of affecting the outcome of legislation. Taft knew that the Memorandum was ethically suspect, which is why he controlled so tightly its dissemination. It is revealing that at first Taft circulated the Memorandum only to the President, with whose structural position vis-a-vis Congress Taft clearly felt a strong affinity.

As Caraway continued to press his legislation, however, Taft grew bolder. In March he wrote to his brother Henry that "We stopped the Caraway bill to take away the power of the Federal Judges in charging a jury, and I am going to take time by the forelock to prime Senator David Reed of Pennsylvania on the probable unconstitutionality of such a law."168 Taft enclosed a copy of his Memorandum, ${ }^{169}$ and in May he suggested to Henry that "If I were you I would open a correspondence with the only man who opposed it in the Senate, and that was Senator Reed of Pennsylvania. You might send a copy of it also to Senator Cummins and another one to Senator Gillett. Don't make me the author of it, for reasons that you will understand." 170

Taft's opposition to the Caraway bill never did erupt into scandal, although this seems more a matter of luck than anything else. The very intensity that Taft brought to the cause of judicial administration betrayed him into actions that could scarcely be defended in public. Of course, on the other side of the coin, it is no doubt due to Taft's vigorous interventions that federal judges enjoy to this day the traditional common law prerogative to comment on the weight of evidence and the credibility of witnesses. ${ }^{171}$ But this result cannot justify the means Taft used, which can only be explained by reference both to the passion of his commitment and to the inherent ambiguities of the English model of a judicial executive administrator. Taft's opposition to S. 624 demonstrates what a dangerous model this could be when transposed to the American context.

\section{IV}

It was said of Taft that the chief justiceship was his "manifest destiny." 172 Certainly he freely admitted that the office was "the ambition of my life."173 When Taft finally attained that ambition, it was after a long career of executive administration: as Governor of the Philippines, Secretary of War, and President of the United States. Taft brought this experience with him as he appropriated the role of Chief Justice and made it his own. It was natural for him to regard the administrative duties of the chief justiceship as analogous to the executive responsibilities with which he was so familiar, especially because there were powerful English precedents for this approach to judicial administration.

The most lasting effect of Taft's unique perspective was its root assumption that the federal judiciary was not a collection of independent judges, but instead a unified branch of government with functional obligations. No Chief Justice after Taft has been able to escape being evaluated on his fulfillment of these obligations. In this regard, Taft did indeed transform the office of Chief Justice. 
But Taft, flush with the enthusiasm of a new idea, and filled with the contacts and assurance of an admired ex-President, pushed this perspective to its natural limits. The difficulty he encountered, but clearly did not fully conceptualize, was that executive administration in the context of a regime of separation of powers contains important elements that are essentially political, and that therefore stand in tension with American ideals of judicial nonpartisanship and with the American institution of judicial review. Taft struggled with this tension throughout his tenure as Chief Justice, acting in ways that fell on different sides of what today might be regarded as obvious ethical boundaries.

Taft truly deserves to be known as the father of federal judicial management. We can learn from his difficulties, however, how subtle and complex is the relationship between the imperatives of judicial management and American norms of proper judicial behavior. Chief Justices after Taft can no longer share his naive Progressive faith in the neutrality of disinterested administration. In our own fallen world of post-Progressive disillusion, Chief Justices must somehow negotiate between the necessities of functional rationality and the requirements of judicial neutrality. If Taft can teach us anything, it is that this negotiation will be neither clear nor easy.

\section{Endnotes}

I From 1913 through 1921 Taft was Kent Professor of Constitutional Law at the Yale Law School.

${ }^{2}$ Herbert Hoover, "Address Commemorating the 20th Anniversary of the Boy Scouts of America," March 10, 1930, Public Papers of the Presidents of the United States: Herbert Hoover, January 1 to December 31, 1930 p. 87 (1976). See "William Howard Taft," The New York Times, March 9, 1930, Section 2, p. 1: "Of some public men, when they pass into the shadowed valley, it is said that they are the most admired of their generation ... but about $\mathrm{Mr}$. Taft there is a universal agreement that he made himself the most loved. Already the language of affection has been exhausted." See "Mr. Taft's Place in All Hearts," Literary Digest, March 22, 1930, p.15; "William Howard Taft," The World, March 10, 1930,p. 10 ("Few men have had his opportunity to watch the attitude of the American people ripen over a period of so many years into a more universal feeling of warm affection and deep confidence.")

Affection for Taft transcended partisan and even ideological lines. The Democratic governor of New York, Franklin Delano Roosevelt, ordered New York state flags to be hung at half staff for thirty days to honor Taft, proclaiming:

The passing of William Howard Taft. . . brings a feeling of universal sorrow to the people of New York. His many years of public service in wide fields and the simplicity and generosity of his personality will be held always in affectionate esteem.

"State Tribute to Taft," The New York Times, March 10,1930, p. 5. Even Senator Hiram Johnson, a progressive follower of Theodore Roosevelt from California, one of only four Senators to vote against Taft's confirmation in 1921, could affirm to the press that

Of recent years I have become very fond of Chief Justice Taft. It was with the utmost regret that I learned of the necessity of his resignation. I feel that he has rendered a great and lasting public service and that his death is a very severe loss to the nation.

"Taft's Life Praised as Truly American," The New York Times, March 9, 1930, p. 26. Taft's accomplishments as Chief Justice can be measured against Johnson's assessment of nine years earlier, on July 1, 1921, when he wrote:

I felt that I would be false to the old Roosevelt fight, false to every principle in which I believed, false to myself, and false to my country, if I voted for Taft's confirmation. . . . Yesterday, we may have changed the course of our country, we may have altered the history of the world by placing in the position where he was the deciding vote in the most powerful tribunal of the universe, a man devoid of learning, judicial temperament, and of principle.

Johnson to Raymond Robins, Hiram Johnson Papers. 3"Leaders Here Laud Character of Taft," The New York Times, March 9, 1930, p. 26. See "Judge Morton Ranks Taft with Greatest: Puts His Service Besides that of Marshall," Boston Globe, February 4, 1930, p. 16.

${ }^{4}$ Robert M. Mennel and Christine L. Compston, eds., Holmes and Frankfurter: Their Correspondence, 1912-1934, p. 249 (University Press of New England 1996).

5 "President Names Hughes Chief Justice as Taft Resigns Because of Ill Health When Trip to Asheville Fails to Aid Him," The New York Times, February 4, 1930 , p. 2.

6 See Valerie Jean Conner, The National War Labor Board: Stability, Social Justice, and the Voluntary State in World War I (University of North Carolina Press 1983).

${ }^{7 * C}$ Chief Justice Taft," Los Angeles Times, July 2, 1921 , p. 4:

Peculiarly enough, Chief Justice Taft has 
enjoyed a vastly greater popularity since he retired from the presidency than during the period when he was the nation's Chief Executive. The tolerant manner in which he endured defeat, the unselfish support he gave to the man who had defeated him for the presidency, the self-effacement which he practiced during the stirring months of the war period, the logic which he brought to bear in supporting the cause of right and justice, both while the fighting was in progress and during the peace negotiations-all these things were noted by the American people and remembered. The almost unanimous approval which greeted his appointment, both by the Senate and by the country at large, goes far to disprove the theory that republics are ungrateful or that they have short memories.

The perception that national public opinion strongly favored Taft was widely shared. See, e.g., "Chief Justice Taft," The Literary Digest, July 16, 1921, p.13. Even The New Republic observed that "The press greets Mr. Taft's appointment with almost universal acclaim." "Mr. Chief Justice Taft," The New Republic, July 27, 1921, Volume 27, p.230.

8 "Taft Gained Peaks in Unusual Career," The New York Times, March 9, 1930, p. 27. The New Republic characterized the remarkable shape of Taft's career in this way:

It can be said of William Howard Taft that at the moment when he leaves the Supreme Court his reputation with the American people is undoubtedly higher than ever before. His term as President saw a steady diminution in his prestige which was reflected in the dismal failure of his candidacy in 1912, at a time when, according to the general political custom of America, he should have had an almost automatic reelection. Since then, by his modesty, geniality and unflagging energy in his work, he has rehabilitated himself to an extent which no one would have ventured to predict eighteen years ago.

"The Week," The New Republic, volume LXI, February 12,1930 , p. 310.

9 "Chief Justice Taft," New York World, February 4, 1930, p. 10.

10 "Judiciary: Hughes for Taft," Time Magazine, Volume XV, No. 6, February 10, 1930, pp. 11-12.

"During the period from October 1922 through July 1929, when Sutherland was on the Court, he authored 142 opinions for the Court. Taft, in contrast, wrote 222 opinions for the Court during that same period. During the six terms between October 1923 and July 1929, when both Butler and Sanford were on the Court, they authored, respectively, 153 and 123 opinions for the Court. Taft wrote 176.

${ }^{12}$ Holmes to Harold J. Laski, January 15, 1922, in Mark DeWolfe Howe, editor, 1 Holmes-Laski Letters: The Correspondence of Mr. Justice Holmes and Harold J. Laski, 1916-1935, p. 398 (Harvard
University Press 1953).

${ }^{13}$ Taft readily admitted that "I have great difficulty myself in the matter" of "judicial style." Taft to Clyde B. Aitchison, December 4, 1925, Taft Papers, Reel 278. Taft wrote plaintively to Holmes in appreciation of Holmes' opinions: "When I read them, I marvel. They read so well and so easily and I ask why can't 1 , but I can't." Letter to Oliver Wendell Holmes, May 6, 1927, Holmes Papers, Reel 38. And he confessed to Holmes that "I regard your power ... to concentrate on the point in few words with admiration and awe." Holmes Papers, Duckett \& Co.v. United States, 266 U.S. 149 (1924).

${ }^{14}$ Sutherland's opinions, although expressing the same general conservative vision as Taft's, are by contrast baldly ideological and so remain in the canon, if only as foils.

15"William Howard Taft," Los Angeles Times, March 10, 1930, p. 4. See Stephen Bonsal, "The Man Who Served Us-Taft," World's Work, April 1930, p. 79: "While as Chief Justice of the United States Mr. Taft delivered several notable opinions of a pioneering quality, it is certain that his words will not be studied and pondered over as, say, the decisions of Marshall, of Taney, or even of Fuller."

${ }^{16}$ Bonsal, "The Man Who Served Us-Taft," World's Work, April 1930, p. 79. The Los Angeles Times opined that Taft's "name will . . be . . . connected with . . . the speeding up and modernizing of the Supreme Court and its reorganization to cope fully with its work. Directly and indirectly, Taft exercised a profound influence on court procedure, and if the law's delay, of which complaint has been made from time immemorial, shall ever cease to be a subject of complaint it will be in large part due to him." "William Howard Taft," Los Angeles Times, March 10, 1930, p. 4.

17 Judge Harry A. Hollzer, quoted in "Jurist Here Adds Tribute," Los Angeles Times, March 12, 1930, p.2.

18 "Two Chief Justices," Washington Post, February 4, 1930, p.6. See "Chief Justice Taft," The Baltimore Sun, February 4, 1930, p.14.

${ }^{19}$ Quoted in "Taft's Life Praised as Truly American," The New York Times, March 9, 1930, p.1. Recall that even during his campaign for the presidency in 1908 , Taft averred that, "Speaking generally, I believe the greatest question now before the American public is the improvement of the administration of justice, civil and criminal, both in the matter of its prompt dispatch and the cheapening of its use." "Taft Wants Quick and Cheap Justice," The New York Times, August 2, 1908, p.1.

${ }^{20}$ Felix Frankfurter, "Chief Justices I have Known," in Felix Frankfurter on the Supreme Court, pp. 487-88 (Belknap Press of Harvard University Press 1970). Frankfurter credited Taft for adapting the federal judicial system "to the needs of a country that had grown from three million to a hundred and twenty million."

${ }^{21}$ See John A. Eagle, "Monopoly or Competition: The Nationalization of the Grand Trunk Railway," The Canadian Historical Review, March 1981, Volume LXII, pp. 3-20; A.W. Currie, The Grand Trunk Railway of Canada (University of Toronto Press 1957); Leslie T. Fournier, Railway Nationalization in 
Canada: The Problem of The Canadian National Railways (MacMillan Co. 1935). Curiously enough, Pierce Butler was at that time appearing before the arbitration panel as counsel for the Canadian government.

${ }^{22}$ McKenna to Taft, July 30, 1921, Taft Papers, Reel 231. McKenney was sixty-nine years old and had been an employee of the Court for the past fifty-two years. 2336 Stat. 1152 ch. 231 (1911).

2436 Stat. 1153 ch. 231 (1911).

${ }^{25}$ William R. Stansbury to Taft, July 30,1921 , Taft

Papers, Reel 231.

${ }^{26}$ Taft to Helen Herron Taft, August 3, 1921, Taft Papers, Reel 28.

${ }^{27} \mathrm{Id}$.

${ }^{28}$ Taft to William R. Stansbury, August 3, 1921, Taft Papers, Reel 231.

29 Taft to Helen Herron Taft, August 3, 1921, Taft

Papers, Reel 28.

${ }^{30}$ Brandeis to Felix Frankfurter, March 6, 1925, in Melvin I. Urofsky and David W. Levy, eds., "Half Brother, Half Son:" The Letters of Louis D. Brandeis to Felix Frankfurter, p.196 (University of Oklahoma Press 1991).

${ }^{31}$ Herbert Little, "The Omnipotent Nine," The American Mercury, Volume XV, No. 57, September 1928, p. 48.

${ }^{32}$ Holmes to Sir Frederick Pollock, October 2, 1921, in Mark DeWolfe Howe, ed., 2 Holmes-Pollock Letters: The Correspondence of Mr. Justice Holmes and Sir Frederick Pollock 1874-1932, p.79 (Harvard University Press 1941).

${ }^{33}$ Holmes to Baroness Charlotte Moncheur, June 2, 1922, Holmes Papers, Reel 26, Frame 761.

${ }^{34}$ Brandeis to Felix Frankfurter, June 28, 1923, in Melvin I. Urofsky, "The Brandeis-Frankfurter Conversations," 1985 Supreme Court Review 299, 313.

${ }^{35}$ Holmes to Sir Frederick Pollock, February 24, 1923, in Mark DeWolfe Howe, ed., 2 Holmes-Pollock Letters: The Correspondence of Mr. Justice Holmes and Sir Frederick Pollock 1874-1932, pp.113-14 (Harvard University Press 1941). Brandeis agreed: "Things go happily in the Conference room with Taft-the judges go home less tired emotionally and less weary physically, than in White's days." Brandeis to Felix Frankfurter, August 6, 1923, in Melvin I. Urofsky, "The Brandeis-Frankfurter Conversations," 1985 Supreme Court Review 299, 322.

${ }^{36}$ Brandeis to Frankfurter, August 6, 1923, in Melvin I. Urofsky, "The Brandeis-Frankfurter Conversations," 1985 Supreme Court Review 299, 321.

${ }^{37}$ Stone to Thomas Reed Powell, January 30, 1940, Stone Papers.

${ }^{38}$ In May 1921, Taft characterized the office of Chief Justice in this way in the course of eulogizing the deceased Chief Justice White: "The Chief Justice is the head of the court, and while his vote counts but one in the nine, he is, if he be a man of strong and persuasive personality, abiding convictions, recognized learning, and statesmanlike foresight, expected to promote teamwork by the court, so as to give weight and solidarity to its opinions." "Chief Justice White," in James F. Vivian, William Howard Taft: Collected Editorials 1917-1921, p. 581 (Praeger 1990).
39 Augustus Hand to Taft, September 18, 1929, Taft Papers, Reel 314 . On Taft's ability to rally the Court, see Henry J. Friendly, "Review of The Unpublished Opinions of Mr. Justice Brandeis," 106 Harvard Law Review 766, 768 (1958). Friendly was Brandeis' law clerk during the 1927 Term. See also David J. Danelski, "The Influence of the Chief Justice in the Decisional Process," in Walter F. Murphy \& C. Herman Pritchett, eds., Courts, Judges, and Politics: An Introduction to the Judicial Process, pp.695-703 (Random House, Inc. 1979).

${ }^{40}$ Robert J. Steamer, Chief Justice: Leadership and the Supreme Court, pp.186-87 (University of South Carolina Press 1986).

4'Taft to H.A. Morrill, December 2, 1908, quoted in Alpheus Thomas Mason, William Howard Taft: Chief Justice, p. 33 (Simon and Schuster 1964).

42 Taft to Alfred C. Meyer, January 28, 1924, Taft Papers, Reel 260.

43 "The Courts and Mr. Taft on Labor," American Federationist, March 1921, p. 220. See Charles Willis Thompson, "The Two Tafts," The American Mercury, Volume I, No. 3, March 1924, pp. 315-19: "[I]n politics Taft was ever all thumbs. ... The general dislike of Taft, which seems so queer a thing when we look back upon it . . . rested upon the fact that 'he cannot ope his mouth but out there flies a blunder." ${ }^{44}$ William Borah, quoted in "Taft Chief Justice of Supreme Court; Confirmed 60 to 4," New York Herald, July 1, 1921, p. 1 .

${ }^{45}$ Speech of the Chief Justice, The Chicago Bar Association Record, Volume 5, No. 3, December 1921, p. 9.

${ }^{46}$ William Allen White, Masks in a Pageant 333-34 (MacMillan Co. 1928).

${ }^{47}$ In his address accepting the 1912 Republican nomination for the presidency, for example, Taft proclaimed:

During this administration we have given special attention to the machinery of government with a view to increasing its efficiency and reducing its cost. ... I have secured an appropriation for the appointment of an Economy and Efficiency Commission, consisting of the ablest experts in the country, and they have been working for two years on the question of how the Government departments may be reorganized and what changes can be made with a view to giving them greater effectiveness for governmental purposes on the one hand, and securing this at considerably less cost on the other.

Speech of William Howard Taft Accepting the Republican Nomination for President of the United States, Senate Document No. 902, $62^{\text {nd }}$ Congress, 2d Session (1912).

${ }^{48}$ Public Law No. 298, 42 Stat. 837 (1922).

${ }^{49}$ Felix Frankfurter and James M. Landis, "The Business of the Supreme Court of the United States-A Study in the Federal Judicial System-Part VI: The Conference of Senior Circuit Judges," 40 Harvard Law Review 431, 456 (1927).

50 The Act provided, however, that the Senior Circuit 
Judge of the designated judge must "consent" to the assignment, and the Senior Circuit Judge of the Circuit to which the designated judge is assigned must certify the need for judicial assistance to the Chief Justice. Although federal judges were preeminently local, there did exist two precedents for the power temporarily to transfer judges. The first was the Act of October 3, 1913, Public Law No. 18, 38 Stat. 203, which authorized the temporary transfer of judges to the Second Circuit in order to alleviate congestion in New York City, and the second was the authorization to appoint circuit judges on the Commerce Court for service on any circuit court. Public Law No. 218, 36 Stat. 539, 540. Felix Frankfurter and James M. Landis, "The Business of the Supreme Court of the United StatesA Study in the Federal Judicial System-Part VI: The Conference of Senior Circuit Judges," 40 Harvard Law Review 431, 447-48 (1927).

st The Act also authorized the appointment of twenty four new district court judgeships, which represented an increase of about twenty five percent in the number of authorized district court judgeships. At the time federal dockets were "particularly swamped" with litigation resulting from the cancellation of wartime contracts and with cases arising from the enforcement of prohibition. See Felix Frankfurter and James M. Landis, "The Business of the Supreme Court of the United States-A Study in the Federal Judicial System-Part VI: The Conference of Senior Circuit Judges," 40 Harvard Law Review 431, 444 (1927).

52 William Howard Taft, "Adequate Machinery for Judicial Business," 7 ABAJ 453, 454 (1921).

${ }^{53}$ Taft to Charles D. Hillis, February 5, 1923, Taft Papers, Reel 250.

${ }^{54} \mathrm{See}$, e.g., William Howard Taft, "The Courts and the Progressive Party," Saturday Evening Post, Vol. 186, No. 39, March 20, 1914, p. 47; William Howard Taft, "Address of the President," 39 American Bar Association Report 359, 383 (1914); William Howard Taft, "The Attacks of the Courts and Legal Procedure," 5 Kentucky Law Journal 3, 13-15 (1916). For a good short summary of the history of the movement to improve the administration of justice in the United States, beginning with Roscoe Pound's epic-making paper, "The Causes of Popular Dissatisfaction with the Administration of Justice," $29 \mathrm{Am}$. Bar Ass'n. Rep. 395 (1906), and in particular of the history to establish judicial councils prior to 1922, see Felix Frankfurter and James M. Landis, "The Business of the Supreme Court of the United States-A Study in the Federal Judicial System-Part VI: The Conference of Senior Circuit Judges," 40 Harvard Law Review 431, 434-43 (1927).

"Note, "Unification of the Judiciary: A Record of Progress," 2 Texas L. Rev. 445, $452-53$ (1924). See Felix Frankfurter and James M. Landis, "The Business of the Supreme Court of the United States-A Study in the Federal Judicial System--Part VI: The Conference of Senior Circuit Judges," 40 Harvard Law Review 431, 455 (1927); "New Law Unifies Federal Judiciary: Chief Justice Made Executive Head of Judicial Council," 6 Journal of the American Judicature Society 69 (1922) ("were it not for the great esteem felt for the Chief Justice, and for his tact and persistence, some- thing far inferior to the actual law would have resulted."); "Courageous Expression by Chief Justice Taft," 6 Journal of the American Judicature Society 67 (1922); “A New Era Opens," 6 Journal of American Judicature Society 67 (1922). Taft later said that "At my suggestion the bill contained a provision for a meeting of a council of judges annually, to consist of the Chief Justice and the senior circuit judge of each circuit, to take into consideration the arrears, where they are, and how they can be provided for by assignment of judges, who have free time to the burdened districts." Taft to Frank Hiscock, April 12, 1922, Taft Papers, Reel 241.

${ }^{56}$ See, e.g., "It Came to Pass-'," 7 Journal of the American Judicature Society 83, 84 (1923).

57" Rally Support for Daugherty Bill: Bar of Entire Country Asked to Lend Assistance in Campaign for Effective Organization of United States Judiciary," 5 Journal of the American Judicature Society 120 (1921). ${ }^{58}$ Felix Frankfurter, "Chief Justices I have Known," in Felix Frankfurter on the Supreme Court 487-88 (Belknap Press of Harvard University Press 1970). 59"The First Conference," $9 A B A J 7$ (1923).

${ }^{60}$ Henry D. Clayton, "Popularizing Administration of Justice," $8 A B A J 43,46$ (1922) (quoting Judge Sheppard).

${ }^{61} I d$.

${ }^{62}$ Taft to E. Cockrell, May 5, 1927, Taft Papers, Reel 291.

${ }^{63}$ William Howard Taft, "The Attacks of the Courts and Legal Procedure," 5 Kentucky Law Journal 3, 1617 (1916). "A judicial force of Judges ought to be under the executive direction of somebody, so that the number of Judges needed to meet the arrears of business at a particular place should be under the control of one who knows what the need is." Taft to Charles F. Ruggles, November 4, 1924, Taft Papers, Reel 268. ${ }^{64}$ Note, "Unification of the Judiciary: A Record of Progress," 2 Texas L. Rev. 445, 445 (1924).

${ }^{65}$ William Howard Taft, "The Courts and the Progressive Party," Saturday Evening Post, Vol. 186, No. 39, March 20,1914, p. 47. "What is needed," wrote Taft, "is a General Director who shall be able to mass judicial force temporarily at places where the arrears are greatest and thus use what is available to do the whole judicial work. There ought to be more unity in the application of Judges at the strategic points where application is needed." Taft to Angus Wilton McLean, December 1, 1924, Taft Papers, Reel 269.

${ }^{66}$ William Howard Taft, "The Attacks of the Courts and Legal Procedure," 5 Kentucky Law Journal 3, 16 (1916). "Somebody . . . ought to be made the chief of the body of Judges who cover a certain territory and have the power to assign the business, so that each Judge shall be bound to follow that assignment. There is not the slightest reason why the same strategy ... should not be secured as you find in large business corporations." Taft to Harry A. Hollzer, February 14, 1928, Taft Papers, Reel 299.

67William Howard Taft, "Address of the President," 39 American Bar Association Report 359, 383 (1914).

${ }^{68}$ Myers v. United States, 272 U.S. 52, 122 (1926).

${ }^{69}$ Taft was not alone in this conception. Thus Frankfurter and Landis write: 
Hundreds of judges holding court in as many or more districts scattered over a continent must be subjected to oversight and responsibility as parts of an articulated system of courts. The judiciary, like other political institutions, must be directed. An executive committee of the judges, with the Chief Justice of the United States at its head, is a fit and potent instrument for the task.

Felix Frankfurter and James M. Landis, "The Business of the Supreme Court of the United States-A Study in the Federal Judicial System-Part VI: The Conference of Senior Circuit Judges," 40 Harvard Law Review 431, 456 (1927).

${ }^{70}$ Taft to John A. Peters, October 11, 1927, Taft Papers, Reel 295. See also Joseph Buffington to Taft, November 16, 1927, Taft Papers, Reel 296; Taft to Ferdinand A. Geiger, November 17, 1927, Taft Papers, Reel 296; Taft to William N. Runyon, March 12, Taft Papers, Reel 300.

${ }^{71}$ Peter G. Fish, "William Howard Taft and Charles Evans Hughes: Conservative Politicians as Chief Judicial Reformers," 1975 Supreme Court Review 123.

${ }^{72}$ Taft to John F. Sater, August 27, 1921, Taft Papers, Reel 233.

${ }^{73}$ Taft to Robert Taft, October 2, 1927, Taft Papers, Reel 295.

${ }^{74}$ Taft to Horace Taft, December 30, 1921, Taft Papers, Reel 237. Taft wrote: "I am trying to get more solidarity of action among the Federal Judges, so that they shall feel that we are all working toward the same end." Taft to Helen Manning, March 25, 1923, Taft Papers, Reel 252.

${ }^{75}$ Taft to Frank S. Dietrich, January 17, 1927, Taft Papers, Reel 288. See James Morton to Taft, June 23, 1925, Taft Papers, Reel 275:

I just received and read the recommendations of the Judicial Conference. I wish you could be a District Judge for a while just to know what excellent work you and the Conference are doing. The recommendation last year about liquor cases,---that the Federal Courts should entertain only the more important ones, - was of the greatest assistance in dealing with the liquor situation. It gave the District Judges solid standing ground from which to urge that course on the United States Attorneys, who are rather inclined to prosecute everybody for everything lest they be accused of favoritism or remissness.

${ }^{76}$ Taft to John S. Partidge, January 22, 1925, Taft Papers, Reel 271. See Taft to John M. Cotteral, May 19, 1926, Taft Papers, Reel 282:

It is too bad that we in the Court here in Washington do not have greater opportunity to meet in the flesh the Judges who are on the firing line in the Federal Judiciary, and who have so much labor thrust on them which they do not have assistance enough properly to dispose of. I am constantly afraid of hearing of the breaking down of some of the District Judges under the burden they have to carry, and I wish you to know that we here at the Nation's Capital are fully conscious of the debt that we and the country owe to you District Judges.

"7aft to William B. Gilbert, December 15, 1924, Taft Papers, Reel 270.

${ }^{78}$ See, e.g., Frank S. Dietrich to Taft, January 12, 1927, Taft Papers, Reel 288; Augustus Hand to Taft, May 31, 1927, Taft Papers, Reel 292.

${ }^{79}$ Learned Hand to Taft, March 1, 1923, Taft Papers, Reel 251. A year later, Hand wrote to Taft:

As I have had occasion to tell you before, $I$ feel I have a vested interest in your being Chief Justice, because you are the first Chief Justice that ever recognized such things as District Courts except when they were officially brought to their attention to reverse.

Learned Hand to Taft, February 8, 1924, Taft Papers, Reel 261.

${ }^{80}$ Taft to Frank S. Dietrich, January 17, 1927, Taft Papers, Reel 288.

${ }^{81}$ Taft to Robert Taft, October 2, 1927, Taft Papers, Reel 295.

${ }^{82}$ By 1925, for example, when Congress was appropriating needed funds for "the purchase of law books ... for United States judges, district attorneys, and other judicial officers," it subjected the distribution of the funds "to the approval of the conference of senior circuit judges." Public Law No. 631, 43 Stat. 1333. Illustrative of the way that Taft personally used the Conference may be found in his campaign to authorize the appointment of extra federal judges in New York City. In a letter to Charles Evans Hughes, Taft asked him to petition Congress for the additional judges, adding "I shall do what I can here, and I shall get the Conference of Senior Circuit Judges . . to take action." Taft to Charles Evans Hughes, March 25, 1925, Taft Papers, Reel 272. Beginning in 1925, the Conference repeatedly recommended the creation of these judgeships. The recommendations figured prominently in Congress's eventual authorization of three additional judges for the Southern District of New York. See Public Law No. 820, 45 Stat. 1317 (1929). See 70 Congressional Record, $70^{\text {th }}$ Cong., 2nd Sess., pp. 17421748 (January 15, 1929). In fact frequent references to the Conference led Representative George Graham to exclaim, "We did not surrender our legislative function when we created" the Conference. Id. at 1743. ${ }^{83}$ Report of the Fourth Conference of Senior Circuit Judges called by the Chief Justice pursuant to the Act of Congress of September 14, 1922, p. 38, Taft Papers, Reel 618. There are many indications of the influence of the Conference's recommendations. Public Law 373, 46 Stat. 774, for example, authorized the hiring of law clerks for circuit judges. $71^{\text {st }}$ Cong., $2^{\text {nd }}$ Sess. (June 17, 1930). The Conference had recommended such a law in 1927,1928, and 1929, and its recommendations figured prominently in the legislative history of the Act. See House Report No. 30, $71^{\text {st }}$ 
Cong., $2^{\text {nd }}$ Sess. (December 12, 1929); Senate Report No. $830,71^{\text {st }}$ Cong., $2^{\text {nd }}$ Sess. (May 29, 1930). In the single month of March 1927, the 69th Congress, in direct response to the recommendations of the Conference, created new judgeships in the Northern District of California (Public Law No. 739, 44 Stat. 1372), the District of Maryland (Public Law No. 700, 44 Stat. 1346), the Western District of North Carolina (Public Law No. 693, 44 Stat. 1339), the Eastern District of Pennsylvania (Public Law No. 701, 44 Stat. 1347), the Western District of New York (Public Law No. 735, 44 Stat. 1370), the Eastern District of Michigan (Public Law No. 747, 44 Stat. 1380), and the District of Connecticut (Public Law No. 703, 44 Stat. 1348). ${ }^{84}$ Thus in March 1927 Congress also created an additional judgeship for the Northern District of New York. Public Law No. 741, 44 Stat. 1374. This judgeship had not been recommended by the Conference, but the Senate Report on the bill quotes at length from a letter by John Sargent, the Attorney General, who states:

Although the northern district of New York was not included among the districts for which the conference of senior circuit judges has recommended additional district judges, Chief Justice Taft, who presides over the conference, has, since the last meeting of the conference, specially examined the situation in the northern district of New York and concluded that an additional district judge is needed there. The Chief Justice says:

"I have been examining the statistics of the cases in the northern district of New York and in the western district, and I am bound to concede that the showing is strong for an additional judge in the northern district as well as in the western district."

Senate Report No. 1557, 69th Congress, 2nd Sess. (February 27,1927).

${ }^{85}$ Thus when Congress authorized the appointment of two extra judges for the Eighth Circuit as recommended by the Conference, Pub. Law No. 555, 43 Stat. 1116 , Taft personally testified in favor of the bill, Senate Report No. 705, 68th Cong., 1st Sess. (June 3, 1924), pp. 1-5. His personal support figured prominently in congressional debates. See 66 Congressional Record, pt. 5, 68th Congress, 2nd Sess., 5202 (March 2, 1925). The day after the passage of the bill Judge William Kenyon of the Eighth Circuit wrote Taft that "there is no doubt in my mind as to who is responsible for its enactment, and I am therefore writing you thanking and congratulating you on behalf of this Circuit. Thou art the man." William Kenyon to Taft, March 4, 1925, Taft Papers, Reel 272.

${ }^{86} \mathrm{So}$, for example, Taft was willing to recommend that the Congress authorize an additional judge for the Western District of Michigan to compensate for the incapacitated Clarence Sessions, even though the Conference had not made any such recommendation. See Public Law 423, 43 Stat. 949; H.R. Report No. 1427, 68th Cong. 2nd Sess. (February 10, 1925) ("This bill has the approval of Chief Justice Taft, who, according to the hearings, has person- ally investigated the physical condition of Judge Sessions.") For a similar example of Taft going outside the recommendations of the Conference, see Public Law No. 663, 45 Stat. 1081 (1929), which created an additional judgeship in the Southern District of Florida. The Senate Report on the bill relies heavily on Taft's personal recommendation. Senate Report No. 631, 70th Cong. 1st Sess. (March 26, 1928). Another example is Public Law No. 528, 43 Stat. 1098, March 2, 1925, which authorized the appointment of a district judge for the District of Minnesota. The authorization was necessary because of the unexpected suicide of Judge John McGee. Although the Conference had not recommended the authorization, the House Report relied upon Taft's personal endorsement. House Report No. 1540, 68th Cong., 2nd Sess. (February 20, 1925). ${ }^{87}$ Taft to Frank H. Hiscock, April 12, 1922, Taft Papers, Reel 241.

${ }^{88}$ Taft to Horace Taft, March 30, 1922, Taft Papers, Reel 240.

${ }^{89}$ Taft to Charles M. Hepburn, April 10, 1923, Taft Papers, Reel 252. Persistence, wrote Taft, "is the only way of getting anything through Congress."

${ }^{90}$ Taft to Horace Taft, October 6, 1921, Taft Papers, Reel 234.

${ }^{9}$ Hearing Before the House Committee on the Judiciary on H.R. 10479, 67th Cong., 2nd Sess., Serial 33, March 30, 1922, p. 10.

${ }^{92}$ Hearing Before Subcommittee of House Committee on Appropriations in Charge of Deficiency Appropriations on the Second Deficiency Appropriations Bill, 69th Cong., 1st Sess., May 13, 1926, p. 766. The next month Taft was "delighted" to notify George W. Anderson of the First Circuit that "the Court of Appeals has ruled in our favor" and authorized the appropriation. Taft to George W. Anderson, June 4, 1926, Taft Papers, Reel 282. See Public Law No. 492, 44 Stat. 841,859 (July 3, 1926).

${ }^{93}$ Taft to Charles P. Taft, 2nd, January 27, 1924, Taft Papers, Reel 260.

94"McReynolds is a Democrat and knows many of the Senators," Taft explained. "Sutherland has been a Senator, and Van Devanter is one of the most forcible of our Court and most learned on questions of jurisdiction." Taft to Thomas W. Shelton, January 31, 1924, Taft Papers, Reel 261. Taft was quite clear "that in my judgment it will help the passage of both bills if I do not make myself prominent in their advocacy."

${ }^{95}$ Hearing Before the Committee on the Judiciary of the House of Representatives on H.R. 8206, 68th Cong., 2nd Sess., December 18, 1924, Serial 45. As Taft said in the context of his proposed legislation that would enable federal courts to merge law and equity and promulgate rules of procedure, "I am determined to push a movement for the betterment of the procedure in the Federal courts. I suppose I weigh down such reform by my advocacy of it, in arousing the opposition of certain elements, especially in the Senate, but I don't know why that should prevent my initiating matters when nobody is likely to do so." Taft to Horace Taft, April 17, 1922, Taft Papers, Reel 241

${ }^{96}$ Chief Justice William H. Rehnquist, "1996 Year-End Report on the Federal Judiciary," The Third Branch, Vol. 29, No. 1 (January 1997), at 1, 6 .

${ }^{97}$ Public Law No. 563, 44 Stat. 1022 (1927). 
${ }^{98}$ Joseph Coursey to Taft, November 23, 1925, Taft Papers, Reel 278.

${ }^{99}$ Taft to Joseph Coursey, November 28, 1925, Taft Papers, Reel 278.

100Joseph Coursey to Taft, December 15, 1925, Taft Papers, Reel 278.

${ }^{101}$ Taft to William D. Mitchell, December 20, 1925, Taft Papers, Reel 278.

102William Mitchell to Taft, January 8, 1926, Taft Papers, Reel 279.

${ }^{103}$ Taft to Albert C. Cummins, January 11, 1926, Taft Papers, Reel 279.

${ }^{104}$ Albert C. Cummins to Taft, January 12,1926 , Taft papers, Reel 279.

105William Mitchell to Taft, March 3, 1926, Taft Papers, Reel 280.

${ }^{106}$ Albert Cummins to Taft, March 5, 1926, Taft Papers, Reel 280.

${ }^{107}$ Public Ledger, July 14, 1921, p.1. See Minneapolis Morning Tribune, July 18, 1921, p.6. For a discussion of Taft's career as a columnist, see James F. Vivian, William Howard Taft: Collected Editorials 1917-1921 (Praeger 1990).

${ }^{108}$ Address to NY Country Bar Ass'n, February 18, 1922, Taft Papers, Reel 590, p.2.

${ }^{109}$ Taft to Clarence Kelsey, August 17, 1923, Taft Papers, Reel 256. See Taft to Charles Evans Hughes, April 26, 1926, Taft Papers, Reel 282 ("Bar Associations are formed too often for merely social enjoyment and fratemization, with only a modicum of effort to ... exert a controlling influence upon the legislative bodies for real reform measures in respect to courts and legal procedure.")

${ }^{110}$ Elihu Root to Taft, September 9, 1922, Taft Papers, Reel 245.

111"Adequate Machinery for Judicial Business," $7 \mathrm{ABAJ}$ 453 (1921).

112"The Chief Justice," 5 The Chicago Bar Association Record pp. 8-13 (December 1921).

${ }^{113} 62$ Congressional Record, pt. 3, 67th Cong., 2nd Sess., pp. 2582-2583 (February 15, 1922). See "Taft's Public Speeches Criticized in the Senate," The New York Tribune, February 16, 1922, p. 2.

${ }_{11462}$ Congressional Record, pt. 3, 67th Cong., 2nd Sess., pp. 2582-2583 (February 15, 1922). Senator Harris also very much objected to Justice Clarke's recent speech urging cancellation of the foreign war debt. See "Justice Clarke Urges Prompt Cancellation of War Debt," Chicago Journal of Commerce, February 9, 1922, p.1; 62 Congressional Record, pt. 3, 67th Cong., 2nd Sess., pp. 2525-2526 (Febnuary 14,1922 ) ("I have the greatest respect and admiration for Justice Clarke . . . . However, I think that the Justices of the Supreme Court of the United States should keep out of any matters that are political. ... I do not think it is the part of wisdom for a Supreme Court Justice to publicly discuss matters to be decided by Congress.") (Remarks of Senator Harris).

"15Address to NY County Bar Ass'n, February 18, 1922, Taft Papers, Reel 590, pp. 2-3. Taft left no doubt about the target of his remarks:

It is a source of some embarrassment for me to rise here and not to talk to you as I would like to talk to you, free from the fetters of the office which I hold. . . I am struggling to be worthy of the bench of which I am a member. I am struggling to fall into the customs and requirements of that position. We have been warned in the Senate of the United States what our narrow function is and with due respect to that warning, I am going to confine myself to a written manuscript.

Id. at 1-2. For press coverage of the speech, see "Taft Approves Laws to Clear Court Dockets," New York Tribune, February 19, 1922, p.13; "Taft Backs Bills to Speed Trials," The New York Times, February 19, p. 18.

${ }^{116}$ Minneapolis Morning Tribune, July 18, 1921, in Taft Papers, Reel 626.

117 Taft's commitment to this position is evident in the Canons of Judicial Ethics that were approved by the ABA in July 1924. Lisa L. Milord, The Development of the ABA Judicial Code 131-143 (American Bar Association 1992). Taft had been appointed in February 1922 as the Chair of the small ABA Committee charged with drafting the Canons. See Cordenio Severance to Taft, February 4, 1922, Taft Papers, Reel 238; Taft to Cordenio Severance, February 9, 1922, Taft Papers, Reel 239. Canon 23 explicitly provides:
A judge has exceptional opportunity to observe the operation of statutes, especially those relat- ing to practice, and to ascertain whether they tend to impede the just disposition of controversies; and he may well contribute to the public interest by advising those having authority to remedy defects of procedure, of the result of his observa- tion and experience.

An early version of this Canon, drafted about June 1922, was even more explicit:

Judges have a peculiar opportunity to observe the operation of statutes, especially those relating to practice, and to ascertain whether they tend to impede the reasonable and just disposition of controversies; they should not be indifferent to shocking results; and they may well contribute to the public interest by advising both the people and their representatives of the result of their observation and experience; there is no need of diffidence in this respect, out of a false fear of being considered to be unduly interfering with another department of the Government.

Judges may well direct diligent effort toward securing from proper authority such modifications of laws or rules tending, in their experience, to impede or prevent the reasonable and just disposition of litigation, as will rectify the evils discovered by them.

Charles Boston to Taft, June 8, 1922, Taft Papers, Reel 242. For the ABA's most recent standard on this subject, see ABA Model Code of Judicial Conduct (1990), Canon 4(B), Comment 1 .

118S. 3151, 70th Cong., 1st Sess. (February 13, 1928). On opposition to federal court diversity jurisdiction in the South and West, see Tony A. Freyer, "The Federal Courts, Localism, and the National Economy, 1865-1900," 53 Business History Review 343 (1979); Harry N. Scheiber, 
"Federalism, the Southern Regional Economy, and Public Policy Since 1865," in David J. Bodenhamer and James W. Ely, Jr., Ambivalent Legacy: A Legal History of the South pp.69-104 (University Press of Mississippi 1984). ${ }^{119}$ See 62 Congressional Record, 67th Cong., 2nd Sess., pt. 5, p. 5108 (April 6, 1922) ("In my judgment we ought to abolish every United States district court in America; we ought to abolish entirely the United States Court of Appeals, and leave nothing of our United States judicial system except the Supreme Court of the United States. We ought to give to State judges and State courts all the jurisdiction.") See George Norris to G. Jay Clark, January 2, 1928, Norris Papers ("In fact, I have gone so far as to advocate the abolition of all Federal courts except the Supreme Court.")

${ }^{120}$ See Senate Report No. 626, 70th Cong., Ist Sess. (March 27, 1928). The Committee Report said simply, "The committee can conceive of no reason why the district court of the United States should have jurisdiction in these cases." Id. at 2 .

${ }^{121}$ Taft to Horace Taft, April 16, 1928, Taft Papers, Reel 301

122Taft to George Wickersham, March 29, 1928, Taft Papers, Reel 300.

${ }^{123}$ Taft to Newton Baker, April 5, 1928, Taft Papers, Reel 301

${ }^{124}$ Taft to Newton Baker, April 19, 1928, Taft Papers, Reel 301.

${ }^{125}$ Taft to Casper Yost, April 5, 1928, Taft Papers, Reel 301. 126"Federal Courts in Peril," St. Louis Daily Globe-Democrat, April 10, 1928, p.18. See Casper Yost to Taft, April 10, 1928, Taft Papers, Reel 301. Taft thanked Yost for the editorials: "I feel sure that they will attract attention." Taft to Casper Yost, April 16, 1928, Taft Papers, Reel 301.

127 Henry Taft was a named partner in the firm of Cadwalader, Wickersham \& Taft.

128Taft to Henry W. Taft, April 5, 1928, Taft Papers, Reel 301. Two days later Taft wrote his brother:

What we desire is publicity. ... You ... might enlarge on the fact that such a bill as this would destroy the jurisdiction in those cases which McReynolds wrote from Oregon and from Nebraska on the right of the Catholics to maintain separate schools and the right of the Germans to maintain separate education in German. If we can stir up the Germans and the Irish and the negroes to an appreciation of the importance to them of maintaining the jurisdiction of the trial courts, we can make the Democrats a bit chary of burning their fingers with such a revolutionary proposal.

Taft to Henry W. Taft, April 7, 1928, Taft Papers, Reel 301 . In a postscript, Taft added, "I am mistaken as to the German language cases. They came from the Supreme Courts of the States. The other came from the U.S. District Court."

${ }^{129}$ See Henry W. Taft to Taft, April 18, 1928, Taft Papers, Reel 301.

${ }^{130}$ See Taft to Willis Van Devanter, April 15, 1928, Van Devanter Papers: "They seem to be slow in New York to take up the question. My brother Harry is preparing the argument for his editorial friends in New York, but he takes so long that they might pass the bill in the Senate before he gets his articles ready,"

${ }^{131}$ Taft to Henry W. Taft, April 21, 1928, Taft Papers, Reel 301.

${ }^{132}$ Henry W. Taft to Taft, April 20, 1928, Taft Papers, Reel 301. Henry W. Taft also drafted a long report on behalf of the ABA Committee on Jurisprudence and Law Reform, and managed to have the ABA Executive Committee go on record against the bill on April 24. Senator Copeland had the Executive Committee resolution, as well as the report of the Committee on Jurisprudence and Law Reform, reprinted in the Congressional Record. 69 Congressional Record $8077-8080$, pt. $8,70^{\text {th }}$ Cong., $1^{\text {st }}$ Sess., May 8, 1928. See also "An Unwise and Dangerous Measure," $14 A B A J 266$ (May 1928).

133 "Senate and Courts," The New York Times, April 22, 1928 , Section 3, p. 4.

13469 Congressional Record 6379 , pt. 6, 70 $0^{\text {th }}$ Cong., $1^{\text {st }}$ Sess., April 13, 1928. Norris refused to hold hearings on the bill, saying that "it is a bill on which I think no particular hearings are necessary. It is entirely a legal proposition. ... It is purely a question of practice that the lawyers on the Judiciary Committee understand as well as do other attorneys." Id. at 6378 .

135 "Senate and Courts," The New York Times, April 22, 1928, Section 3, p. 4.

${ }^{136} 69$ Congressional Record 7421-7422, pt. 7, 70 Cong., $1^{\text {st }}$ Sess., April 30, 1928. See "Whittling Away at the Federal Tribunals," $14 A B A J 200$ (1928). The $A B A J$ editorial particularly objected to the Bill's repudiation of diversity jurisdiction:

In an address at the San Francisco meeting of the American Bar Association, Chief Justice Taft, while disclaiming any discussion of legislative policy, made the following pertinent remarks by way of comment on the proposal to relieve the Federal courts of congestion by taking away this jurisdiction:

"I venture to think that there may be a strong dissent from the view that danger of local prejudice in State Courts against nonresidents is at an end. Litigants from the eastern part of the country who are expected to invest their capital in the West or South will hardly concede the proposition that their interests as creditors will be as sure of impartial judicial consideration in a Western or Southern state as in a federal court.

The material question is not so much whether the justice administered is actually impartial and fair, as it is whether it is thought to be so by those who are considering the wisdom of investing their capital in States where that capital is needed for the promotion of enterprises and industrial and commercial progress. No single element ... in our governmental system has done so much to secure capital for the legitimate development of enterprises throughout the West and South as the existence of Federal courts there, with a jurisdiction to hear diverse citizenship cases."

Taft had addressed the San Francisco meeting of the American Bar Association on August 10, 1922. His 
speech is reproduced in full in 6 Journal of the American Judicature Society 36 (1922), and in 57 The American Law Review 1 (1923). In his address before the ABA, Taft had also been careful to observe: "But of course the taking away of fundamental jurisdiction from the Federal Courts is within the power of Congress, and it is not for me to discuss such a legislative policy." $I d$. at 11 .

Brandeis did not accept Taft's point about the importance of diversity jurisdiction for facilitating the investment of eastern capital in western and southern states:

He speaks feelingly on the subject whenever it comes up. I think his point is theoretical, like much of the economists mouthing of the "rational man." Of course, the bankers \& still less the investors, do not give the subject of litigation any thought when they make loans.

Brandeis to Felix Frankfurter, May 10, 1928, in Melvin I. Urofsky and David W. Levy, eds., "Half Brother, Half Son:" The Letters of Louis D. Brandeis to Felix Frankfurter p. 331 (University of Oklahoma Press 1991). Frankfurter later published an article thanking Norris for sponsoring S. 3151 and thereby provoking discussion about the appropriate scope of federal jurisdiction, in which he virtually reiterated (without attribution) Brandeis' comments about diversity jurisdiction. Felix Frankfurter, "Distribution of Judicial Power Between United States and State Courts," 13 Cornell L. Q. 499, 499 n.1, pp. 521-22 (1928).

${ }^{137} 69$ Congressional Record 7422 , pt. $7,70^{\text {th }}$ Cong., $1^{\text {st }}$ Sess., April 30, 1928.

${ }^{138}$ S. 3151, 70th Cong., Ist Sess., May 8, 1928. See 69 Congressional Record 8077, pt. 8, May 8, 1928. Somehow Taft managed to acquire a copy of a letter sent by Norris to Lewis Gannett of The Nation explaining the proposed change in S. 3151. In the letter Norris writes that the "principal object of this bill . . . is to take away the jurisdiction of the Federal Courts in the diversity of citizenship. It is true the bill takes away some other jurisdictions, but the other items we thought were of very little importance. However, there is no objection to amending the bill so as to confine it entirely to diverse citizenship cases." Norris to Gannett, April 28, 1928. Taft sent the letter to Willis Van Devanter, dryly commenting: "I send you herewith a copy of a letter written by Norris . . . showing how closely he scrutinized the effect of his bill before introducing it." Taft to Willis Van Devanter, May 4, 1928, Taft Papers, Reel 301.

${ }^{139}$ Taft to Henry W. Taft, May 16, 1928, Taft Papers, Reel 302.

${ }^{140}$ Hearings Before the House Committee on the Judiciary on H.R. 6687, 70th Cong., 1st Sess., February 1, 1928, p. 6.

${ }^{141}$ Taft to Thomas Walsh, May 8,1928 , Taft Papers, Reel 301.

${ }^{142} I d$.

${ }^{143} \mathrm{Id}$.

${ }^{144}$ Thomas Walsh to Taft, May 10, 1928, Taft Papers, Reel 301. The next day Taft wrote to A.C. Paul that "I sincerely hope that [Walsh] will be able to get the bill through. I fear that the Chief Justice of the Court of Customs Appeals will try to prevent it, but I hope not." Taft to A.C. Paul, May 11, 1928, Taft Papers, Reel 301. ${ }^{145}$ Public Law No. 914, 45 Stat. 1475.

14628 U.S.C. Section 211 (1964 ed.).

${ }^{147}$ Glidden Co. v. Zdanok, 370 U.S. 530 (1962). The story is well told in Brenner v. Manson, 383 U.S. 519, 526 (1966).

${ }^{148}$ This same dilemma now occurs whenever the Supreme Court is itself called upon to promulgate rules. So, for example, Justices Douglas and Black have dissented from the Court's promulgation of Rules of Civil Procedure on the grounds, inter alia, that rulemaking authority should be transferred to "the Judicial Conference" in order to "relieve us of the embarrassment of having to sit in judgment on the constitutionality of rules which we have approved and which as applied in given situations might have to be declared invalid." 374 U.S. 869-70 (1963). Taft was, of course, a great supporter of increasing the rulemaking authority of the Supreme Court.

${ }^{149}$ Thus Augustus Hand wrote Taft: "Our only real relief is to get rid of petty criminal cases. If we do not do this, this court which has been one of the most important and interesting trial courts anywhere is bound, in my opinion, to sink to a very low level." Augustus Hand to Taft, December 9, 1925, Taft Papers, Reel 278. Exemplary is Henry Smith's letter to Taft explaining why he was retiring as a federal district judge:

I am not conscious of any disability, physical or mental, and would dislike to be considered "shirking," but the burden of the immense criminal business of a police character-especially the flood of liquor cases-has become very great. They involve no questions of legal importance. Just one small criminal case after another, depending wholly upon testimony as to the facts. My egotism, I suppose, persuades me that I am a little thrown away on such work, and impels me to think I had better turn it over to a younger, stronger, and less susceptible mind.

Henry A.M. Smith to Taft, May 23, 1923, Taft Papers, Reel 253.

${ }^{150}$ Indeed, in appointing Taft, Harding announced that he expected Taft to move rapidly to remedy the congestion overtaking federal courts. "Additional judges will be needed," he said, and "there may be need of authorization of commissioners; something must be done to relieve the courts of cases of the less criminal type. I mean cases growing out of the Volstead act." Gus Karger to Taft, June 30, 1921, Taft Papers, Reel 227. See George F. Authler, "Taft Confirmed by Senate for Post of Chief Justice," The Minneapolis Morning Tribune, July 1, 1921, p. 1.

151"The Federal Judicial Council," 2 Texas Law Review 458,461 (1924). The Conference noted that this reform "would be expedient, provided the machinery proposed is within constitutional limits." Id. 152Taft to Horace Taft, September 30, 1923, Taft Papers, Reel 257.

${ }^{153}$ Taft to Albert Cummins, December 3, 1925, Taft Papers, Reel 278; Taft to George Graham, December 
3, 1925, Taft Papers, Reel 278, Ever tactful, Taft sent a similar letter to Senator Thomas Walsh, the most influential Democrat on the Senate Judiciary Committee. Taft to Thomas Walsh, December 3, 1925, Taft Papers, Reel 278. Walsh replied that "We are so near together in our ideas concerning the measure for the relief of the District Judges that there should be no difficulty in meeting each other's views." Walsh preferred, however, to lodge the appointment power in the President rather than the District courts. Thomas Walsh to Taft, December 4, 1925, Taft Papers, Reel 278. Taft responded that he did "not wish to insist on the appointment by the District Judges," and that he would be "glad to talk further with you about it, because something ought to be done." Taft to Thomas Walsh, December 5, 1925, Taft Papers, Reel 278.

Taft also asked Augustus Hand for his comments on the proposed legislation. Hand responded "Of course I am heartily in favor of such a plan though I have not looked up the law and do not know whether the appointment of magistrates for such a tribunal as you propose can be delegated to the courts." Augustus Hand to Taft, December 9, 1925, Taft Papers, Reel 278.

${ }^{154} 67$ Congressional Record 10942 , pt. 10, 69 $9^{\text {th }}$ Cong., $1^{\text {st }}$ Sess., June 8, 1926. Graham continued:

One of the great difficulties has arisen by reason of the invasion of what belonged heretofore to the States alone through the adoption of the eighteenth amendment. By the adoption of that amendment a great burden of police work was cast upon the Federal Government without furnishing that Government the proper equipment and machinery for carrying on the work created by the adoption of the eighteenth amendment and the laws intended to carry it into effect. That is one reason why the business of the courts is suffering, why the courts are congested ....

Id.

${ }^{155} I d$.

${ }^{156}$ Id. at 10942-43.

${ }^{157}$ Francis G. Caffey to Taft, March 17, 1927, Taft Papers, Reel 290. See, e.g., Hearings before the House Committee on the Judiciary on H.R. 5608, H.R. 8230 , H.R. 8555, and H.R. 8556, 70th Cong., 1st Sess., January 17,1928 , p.13 (Testimony of Francis G. Caffey referring to the 1923 recommendation of the Conference of Senior Circuit Court Judges).

${ }^{158}$ Taft to Francis G. Caffey, March 21, 1927, Taft Papers, Reel 290. "[B]ut my interest in it is deep," continued Taft, "and I am glad to express the hope that united action will be taken to have the next Congress approach the subject and do the best it can." Pushed by Representative Walton Moore of Virginia, debate on expanding the powers of United States Commissioners continued sporadically throughout the decade. See, e.g., Taft to Walton Moore, March 21, 1927, Taft Papers, Reel 290; Walton Moore to Taft, March 22, 1927, Taft Papers, Reel 290; Taft to Walton Moore, March 23, 1927, Taft Papers, Reel 290. The
Wickersham Commission also endorsed legislation of this kind. See George Cochran Doub and Lionel Kestenbaum, "Federal Magistrates for the Trial of Petty Offenses: Need and Constitutionality," 107 University of Pennsylvania Law Review 443, 452-53 (1959).

${ }^{159} \mathrm{Caraway}$ had been attempting to promote this reform for many years. See, e.g., Ashley Cockrill, "Trial by Jury," 52 American Law Review 823 (1918).

${ }^{160}$ William Howard Taft, "Delays and Defects in the Enforcement of Law in This Country," 187 North American Review 851, 857 (1908).

${ }^{161}$ See, e.g., William Howard Taft, "The Courts and the Progressive Party," Saturday Evening Post, Vol. 186, No. 39, March 20, 1914, p. 47:

[S] tate legislatures have cut down the power of the judge so that now in many states he has little more power to exercise than the moderator in a religious conference. In some states he is required to deliver a written charge before argument of counsel, and in others he is permitted only to accept or reject the statements of the law as given by counsel. His opportunity for usefulness is curtailed, his impartiality made the subject of suspicion by most unwise restrictions, and the trial is turned over largely to the control of the lawyers and the little restrained discretion of the jury. The result has been the perversion of justice in jury trials, the infusion into them of much maudlin sentiment and irrelevant considerations, and a dragging out of the trial to such a length that if it be a civil case the cost of litigation is greatly increased, and if it be a criminal case the public come to treat it as a game of wits and eloquence of counsel rather than the settlement of a serious controversy in a court of justice. Neither the dignity nor the effectiveness of judicial administration under these conditions impresses itself upon the public.

${ }^{162}$ Taft to Helen Herron Taft, April 30, 1924, Taft Papers, Reel 639. Taft continued: "Congressman Snell, who is the Chairman of the Committee on Rules in the House, promised me that he could postpone the bill. I saw the Chairman of the Judiciary Committee, Mr. Graham, and he thinks he can. I think I shall try and see Nick Longworth, the leader of the House, tomorrow, and with those agreed, I hope the plan of delay can be carried out. It will be a good deal easier to induce the President to veto the bill after the election than before."

${ }^{163}$ Taft to Thomas W. Shelton, April 13, 1924, Taft Papers, Reel 263. Taft noted that "I am not in a position to appear before the committee myself, because were I to oppose it, it would only sharpen the eagerness of many to put it through." Taft to Gardiner Lathrop, April 27, 1924, Taft Papers, Reel 264. On Bar opposition to the measure, see "The Effort to Limit Power of Federal Judges," $10 A B A J 303$ (1924) ("The bill is part and parcel of a vicious plan to destroy the powers and independence of the Federal Judiciary, and to invade 
its constitutional prerogatives."); "An Unwise Measure," 10 ABAJ 332 (1924) ("[T]he proposal is wholly indefensible. ... The indisputably greater efficiency of the federal courts as compared with the vast majority of state courts, of English criminal courts as compared with our own, rests on the power which the presiding judge has to control the proceedings.") Compare "Letters of Interest to the Profession," $10 \mathrm{ABAJ}$ 443 (1924) (letter of C. Floyd Huff) ("[A] jury trial is a mockery far more so under a system which permits a Judge to make the last argument to the jury.") See also id (letter of Alvah J. Rucker). Compare Harry Eugene Kelly, "An Impending Calamity," 11 ABAJ 65 (1925) with "Curbing Federal Judges," 28 Law Notes 182 (1925).

${ }^{164}$ Memorandum, December 2, 1924, Taft Papers, Reel 639.

${ }^{165} \mathrm{Id}$. at 1.

${ }^{166} \mathrm{Id}$. at 6.

$1671 d$. at 12 .

${ }^{168}$ Taft to Henry W. Taft, March 27, 1925, Taft Papers, Reel 272.
${ }^{169}$ Henry W. Taft to Taft, March 28, 1925, Taft Papers, Reel 273.

${ }^{170}$ Taft to Henry W. Taft, May 28, 1925, Taft Papers, Reel 274 . Henry responded by sending to Taft a "copy of the proposed report of the [ABA] Committee on Jurisprudence and Law Reform, which I prepared some weeks ago. . . . You will see from the report that I used your memorandum on the Caraway bill freely, adding something of my own." Henry W. Taft to Taft, May 29, 1925, Taft Papers, Reel 274.

${ }^{171}$ See Wright and Miller, 9 Federal Practice and Procedure Civil 2d Section 2557 (1995); Jack B. Weinstein and Margaret A. Berger, 1 Evidence Section 107 (Matthew Bender 1994). See Quercia v. United States, 289 U.S. 466, 469 (1933) ("In a trial by jury in a federal court, the judge is not a mere moderator, but is the governor of the trial for the purpose of assuring its proper conduct ....")

${ }^{172}$ Ernest Knaebel to Taft, July 1, 1921, Taft Papers, Reel 228.

173“"Taft Awed By Gaining Goal of His Ambition," New York Herald, July 1, 1921, p.2. 